\title{
Continuous Reactive Coupling of Glycerol and Acetone - a Strategy for Triglyceride Transesterification and In-situ Valorisation of Glycerol by-product
}

\author{
Valentine C. Eze ${ }^{\mathrm{a}}$, Adam P. Harvey ${ }^{\mathrm{a}}$ \\ ${ }^{a}$ School of Engineering, Newcastle University, NE1 7RU, UK. \\ Corresponding: Tel.: +44-191-208-5747; E-mail address: v.eze@ncl.ac.uk (Valentine C. Eze)
}

\begin{abstract}
Methyl esters of fatty acids are widely used as biodiesel, a sustainable replacement for petro-diesel. The conventional biodiesel process produces crude glycerol, which constitutes about $10 \mathrm{wt} \%$ of the total products. This has led to a surplus of crude glycerol due to global increase in biodiesel use, necessitating increased research into sustainable processes that could convert the crude glycerol into higher value-added products. This study investigates biodiesel processes for continuous transesterification of triglycerides to methyl esters, coupled to conversion of the glycerol by-product into solketal, a value-added product, via reaction with acetone in situ. The study was carried out using one-stage and two-stage catalytic transesterification of triacetin and methanol in mesoscale oscillatory baffled reactors (meso-OBRs). The two-stage process involved two meso-OBRs in series packed with Amberlyst $^{\mathrm{TM}}$ resin catalysts: a basic Amberlyst ${ }^{\mathrm{TM}} \mathrm{A} 26-\mathrm{OH}$ in the first stage to catalyse transesterfication of triacetin with methanol, and an acidic Amberlyst ${ }^{\mathrm{TM}} 70-\mathrm{SO}_{3} \mathrm{H}$ in the second stage to catalyse the coupling of glycerol and acetone to form solketal. One-stage triacetin transesterification and glycerol coupling with acetone was carried out in a meso-OBR packed with the acidic Amberlyst ${ }^{\mathrm{TM}} 70-\mathrm{SO}_{3} \mathrm{H}$ resin. In the two-stage process, the triacetin was converted to $99.1 \pm 2.0 \%$ methyl acetate and $98.0 \pm 1.3 \%$ glycerol after $25 \mathrm{~min}$ residence time in the first reactor and the glycerol was reacted with acetone in the second reactor to achieve $76.5 \pm 2.8 \%$ solketal conversions after $35 \mathrm{~min}$. The single-stage process achieved $48.5 \pm 2.7 \%$ solketal conversion after $30 \mathrm{~min}$. The meso-OBR was operated continuously to achieve high quality steady states and consistent triacetin conversions. The triglyceride transesterification with reactive coupling of glycerol with acetone produces less crude glycerol by-product. This process strategy could be optimised for future biodiesel production.
\end{abstract}


Keywords: Reactive coupling, methyl esters, solketal, Amberlyst ${ }^{\mathrm{TM}}$ resin catalysts, acetalisation, mesoscale oscillatory baffled reactors (meso-OBRs).

\subsection{Introduction}

Fatty acid methyl esters are the main constituents of biodiesel, a product that is widely used as alternative to petro-diesel. These esters are mostly produced via transesterification of triglycerides with methanol using acid and base catalysts, in a process which produces $10 \mathrm{wt} \%$ crude glycerol as a byproduct (Figure 1). The most commonly applied method for biodiesel production is the base-catalysed homogeneous process using alkali-metal hydroxides and methoxides [1-3], particularly sodium methoxide [3]. The biodiesel produced by this method is majorly a mixture of fatty acid methyl esters (FAME). These alkali catalysts are commonly used because of their high catalytic activity which leads to high biodiesel yield at a short reaction time compared to acid-catalysed processes [4].

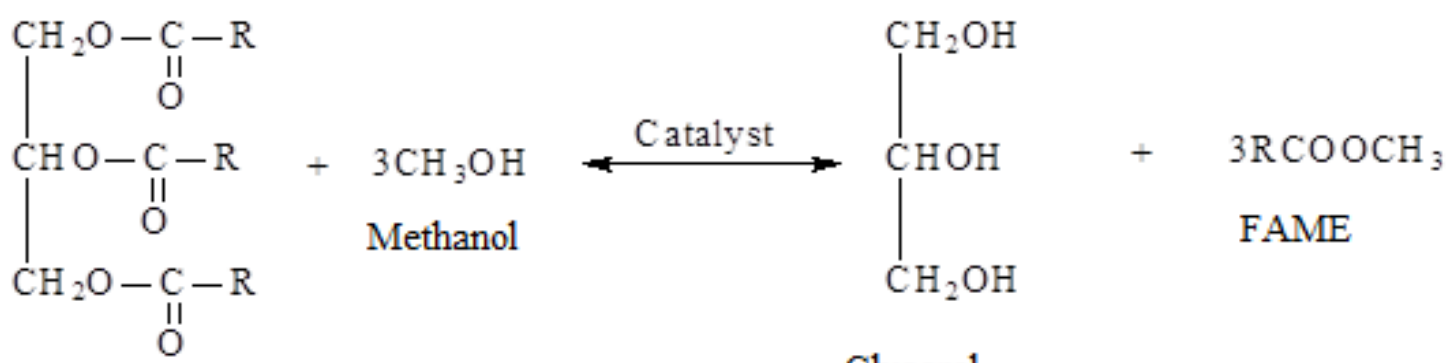

Triglyceride

Glycerol

Figure 1: Transesterification reaction for biodiesel production

However, the use of homogeneous catalysts comes at a great cost. It necessitates various operating and capital costs downstream, arising from the inability to recover the catalyst for further use and the large amount of water and energy required for the washing and drying of the biodiesel. The crude glycerol by-product from the conventional process commands low market prices because of contamination by salts formed from the catalyst neutralisation. Heterogeneous catalysis of biodiesel production [5, 6] would address many of these problems. It would eliminate or minimise the cost of the downstream 
processing steps associated with the use of homogeneous catalysts. The crude glycerol produced through heterogeneous catalysis would be of higher quality and command a higher market price, adding to the profitability of commercial biodiesel. Another huge advantage of heterogeneous catalysts is the removal of the costs of continual catalyst replacement. This is a "greener" strategy for productions of valuable chemicals, including biodiesel.

Studies on heterogeneous catalysis of biodiesel production reactions have shown that anion $\left(\mathrm{OH}^{-}\right)$ exchange resins [7-9] and cation $\left(-\mathrm{SO}_{3} \mathrm{H}\right)$ exchange resins [10-12] are promising catalysts. Catalysis

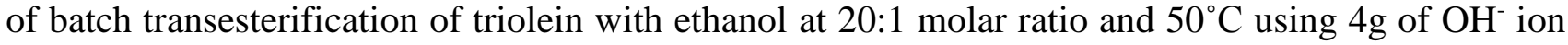
exchange resins (PA306) was used to achieve over $98 \%$ yield of fatty acid ethyl esters after 5 h reaction time without catalyst deactivation[7]. Another study also showed that 70\% FAME yield was achieved after $0.18 \mathrm{~h}$ residence time for continuous methanolysis of coconut oil with $\mathrm{OH}^{-}$anion exchange resin at $6: 1$ methanol to oil molar ratio and $60^{\circ} \mathrm{C}$, without catalyst deactivation after 10 cycles [8]. No catalyst deactivation was reported for transesterification of soybean oil with methanol with $3 \mathrm{~g}$ of $\mathrm{OH}^{-}$ anion exchange resin (BRI), where reactions at $150: 1$ methanol to soybean oil molar ratio and $80^{\circ} \mathrm{C}$ was used to achieve $97.3 \%$ FAME yield after $4 \mathrm{~h}$ reaction time [9]. One of the cation-exchange resins that have been reported for catalysis of triglyceride transesterification is PTSA $-\mathrm{SO}_{3} \mathrm{H}$. The PTSA $\mathrm{SO}_{3} \mathrm{H}$ resin was used to catalyse batch transesterification of babaçu oil to obtain $98 \%$ FAME yield after $8 \mathrm{~h}$ reaction time at 30:1 methanol to oil molar ratio, $\sim 65^{\circ} \mathrm{C}$ and $7 \mathrm{wt} \%$ of the catalyst [12].

These studies on ion-exchange resins catalysts clearly demonstrate that they potentially have significant advantages in terms of operational stability over other catalysts, notably doped and undoped metal oxides[13], and could be tailored towards heterogeneous catalysis of biodiesel production. Therefore, it is envisaged that the use of hydroxide and sulphonic acid functionalised resin catalysts for biodiesel production will produce glycerol of high market value, increasing the commercial viability of biodiesel production. 
Although glycerol produced using heterogeneous catalysts is of higher quality than the crude glycerol from the homogeneously catalysed process, currently it seems that co-production of glycerol of high purity has little economic advantage on biodiesel plants. This is because glycerol oversupply has significantly reduced the glycerol price [14]. The huge rise in global glycerol production has caused surplus of glycerol, from only 200,000 tonnes in the year 2003, to over 2 million tonnes in 2011; and this is predicted [15] to rise to over 6 million tonnes in 2025. The negative impact of glycerol oversupply on the glycerol market has been enormous. A study [15] has shown that crude glycerol has effectively become a waste product, as the price has crashed to $\sim € 0$ per tonne, whereas the market price for refined glycerol (99.5\% Kosher grade) has decreased from $€ 4000$ per tonne in the year 2000 , to about $€ 450$ per tonne in 2010 . These trends demonstrate that a paradigm shift in biodiesel processing technology is necessary to ensure sustainability of the biodiesel industry.

Various studies have been carried out on transformation of glycerol into valuable products, such as glycerol carbonate [16-18] and solketal [19-22]. Glycerol carbonate has applications as a curing agent in cement and concrete building, solvent for active medical ingredients in various pharmaceutical formulations, an electrolyte in lithium and lithium-ion batteries, and in production of various polymers and plastics [23, 24]. Solketal is one of most useful derivatives of glycerol, produced via acid-catalysed condensation of glycerol with acetone (Figure 2). Solketal has applications as a fuel additive [25, 26], surfactant and flavouring agent [19]. As a fuel additive, solketal can be utilised by blending in biodiesel [25], or gasoline [26]. The use of solketal as an additive for biodiesel allows for modifications in the current biodiesel processing technology, by producing biodiesel that already contains a solketal fuel additive. 


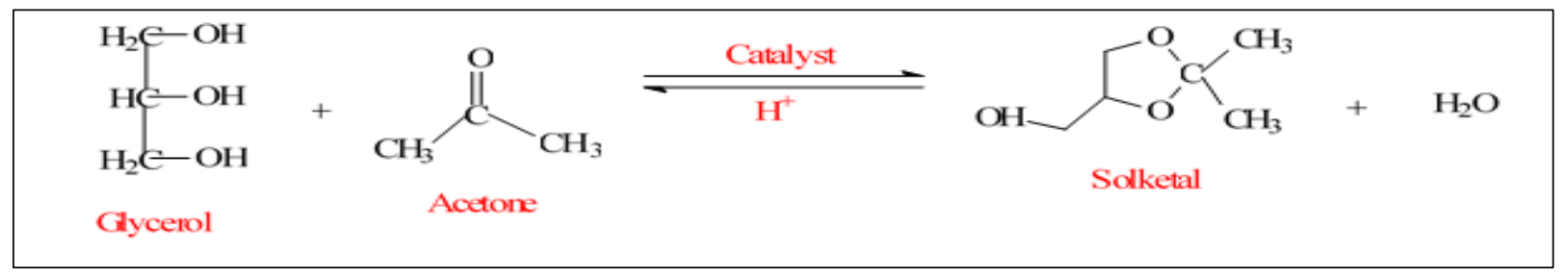

Figure 2: The acid-catalysed reaction of glycerol and acetone to form solketal.

This study was carried out using oscillatory baffled reactors (OBRs) as a process development reactor platform, partly to ensure that mass transfer effects are negated. The liquid-liquid reaction in homogeneous biodiesel processing becomes instead a three-phase liquid-liquid-solid reaction when using heterogeneous catalysts, and this requires strong mixing to ensure mass transfer independence. Process intensification reactors are at the heart of current drive for Green Chemistry processes, allowing for a more efficient utilisation of raw materials, energy efficiency and safer operation through smaller volume of reactors and lower system footprints [27]. Other "intensified" reactors that have been studied for biodiesel production reactions include microwave reactors [28, 29], ultrasonic reactors [30-32] spinning disc reactors [33] and micro-reactors [34-36]. The advantages of OBRs [6, 37-39] are ease of scale up, reproducibility of experiments, compatibility with homogeneous and heterogeneous catalysts, and potentials for operations in batch and continuously as a plug flow reactor. Mixing in the OBR is independent of net flow and controlled by an oscillatory flow, allowing reactions that require residence times up to hours to be operated in a continuous mode with a greatly reduced ratio of length to diameter. The effectiveness of mixing and radial transport in OBRs are controlled by the net flow Reynolds number $\left(\operatorname{Re}_{n}\right)$ and the oscillatory Reynolds number $\left(\mathrm{Re}_{\mathrm{o}}\right)$ [38].

$$
\begin{aligned}
& R e_{n}=\frac{\rho \mathrm{uD}}{\mu} \\
& R e_{o}=\frac{2 \pi \mathrm{f} x_{0} \rho \mathrm{D}}{\mu}
\end{aligned}
$$


Where:

$\mathrm{f}$ : oscillatory frequency $(\mathrm{Hz})$, xo: centre-to-peak amplitude of oscillation (m)

$\mu$ : dynamic viscosity of the reactant mixture (Pa.s), $\rho$ : density of the reactant mixture $\left(\mathrm{kg} / \mathrm{m}^{3}\right)$,

$\mathrm{D}$ : internal diameter of the baffled tube $(\mathrm{m})$

This study investigates biodiesel processes for integrated triglyceride transesterification to form methyl esters, and in-situ conversions of the glycerol by-product into solketal via reactive coupling with acetone (Figure 3).

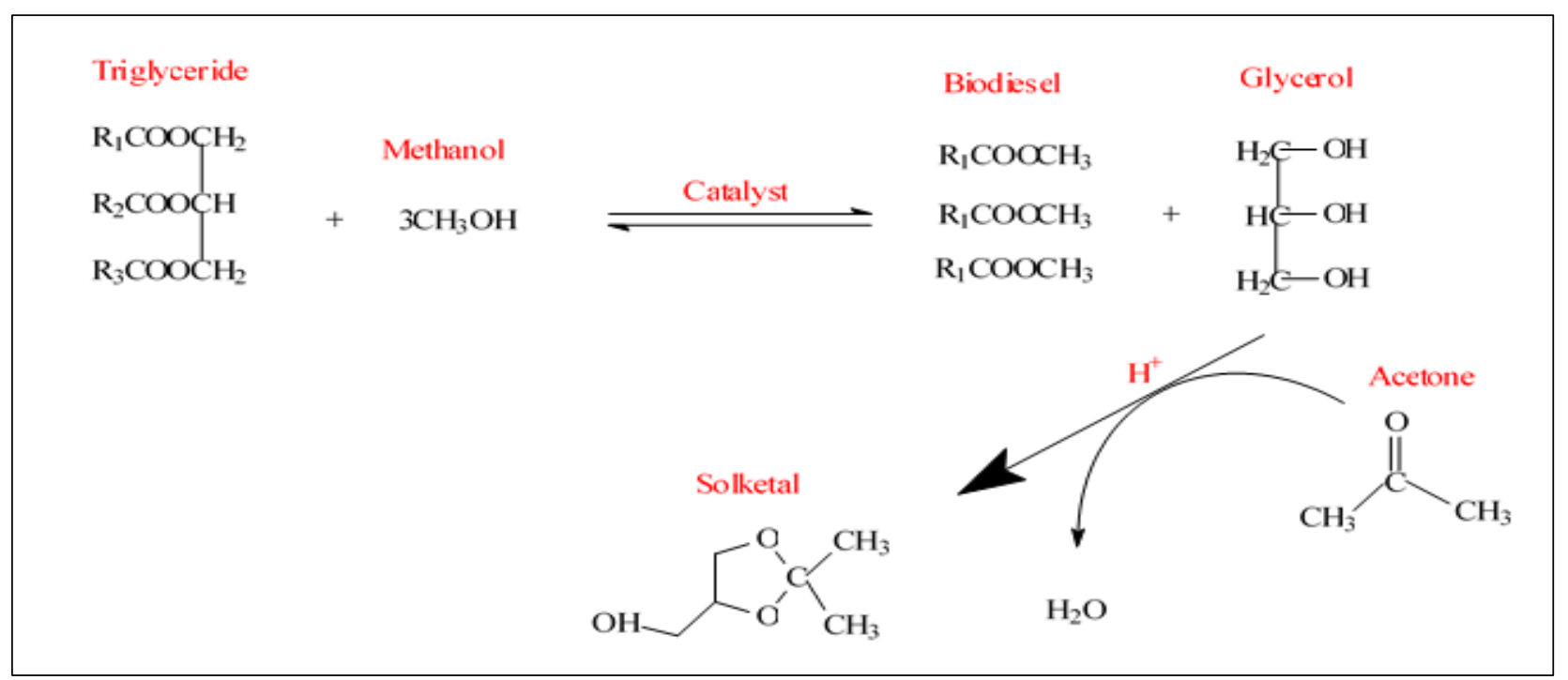

Figure 3: Reaction scheme for integrated triglyceride transesterification and acetalisation of glycerol.

This new process produces biodiesel and solketal which are both combustible fuels and would require no downstream separations after recovery of excess methanol and acetone. Triacetin was used as a representative triglyceride due to its fast reaction rate which allows for rapid screening of the proposed reactions. The study investigates possible routes for achieving simultaneous conversions of glycerol to solketal in biodiesel plants using basic $\left(-\mathrm{OH}^{-}\right)$and acidic $\left(-\mathrm{SO}_{3} \mathrm{H}\right)$ ion exchange resin catalysts. The ion-exchange catalysts were selected for these reactions because of their reported catalytic stability as heterogeneous catalysts. Small scale OBRs (meso-OBRs) were used because of their small volume (a few millilitres), which allows significantly smaller amounts of reagents to be used and minimises the amounts of waste generated. 


\subsection{Materials and Methods}

\subsection{Materials}

Materials used in the experiments were triacetin (99\%, Sigma-Aldrich), anhydrous methanol (99.8\%, Sigma-Aldrich), methyl acetate (99\%, Sigma-Aldrich), glycerol (99\%, Sigma-Aldrich), solketal (98\%, Sigma-Aldrich), toluene (99.9\%, Sigma-Aldrich) and 2-propanol (99.9\%, Sigma-Aldrich). The hydroxide (Amberlyst $\left.{ }^{\mathrm{TM}} \mathrm{A} 26-\mathrm{OH}\right)$ and sulphonic acid (Amberlyst ${ }^{\mathrm{TM}} 70-\mathrm{SO}_{3} \mathrm{H}$ ) functionalised styrenedivinylbenzene copolymer catalysts were obtained from the Dow Chemical Company, Netherland. Physical and chemical properties of the Amberlyst ${ }^{\mathrm{TM}}$ resin catalysts used could be found in the product datasheets and have been reported elsewhere [40, 41].

\subsection{Experimental Procedures}

The Amberlyst ${ }^{\mathrm{TM}}$ resins were packed in a variety of meso-OBRs and screened individually for catalysis of triacetin transesterification (Amberlyst ${ }^{\mathrm{TM}} 70-\mathrm{SO}_{3} \mathrm{H}$ and Amberlyst ${ }^{\mathrm{TM}} \mathrm{A} 26-\mathrm{OH}$ ) and glycerol reaction with acetone (Amberlyst ${ }^{\mathrm{TM}} 70-\mathrm{SO}_{3} \mathrm{H}$ ). The meso-OBRs used has been previously reported [42]. The reactors were jacketed, integrally baffled glass tubes of about 770mm length, $8 \mathrm{~mm}$ outer diameter, $5 \mathrm{~mm}$ inner diameter and periodic constrictions of $2.5 \mathrm{~mm}$ diameter along the length of the tube at $7.5 \mathrm{~mm}$ spacing (Figure 4). 

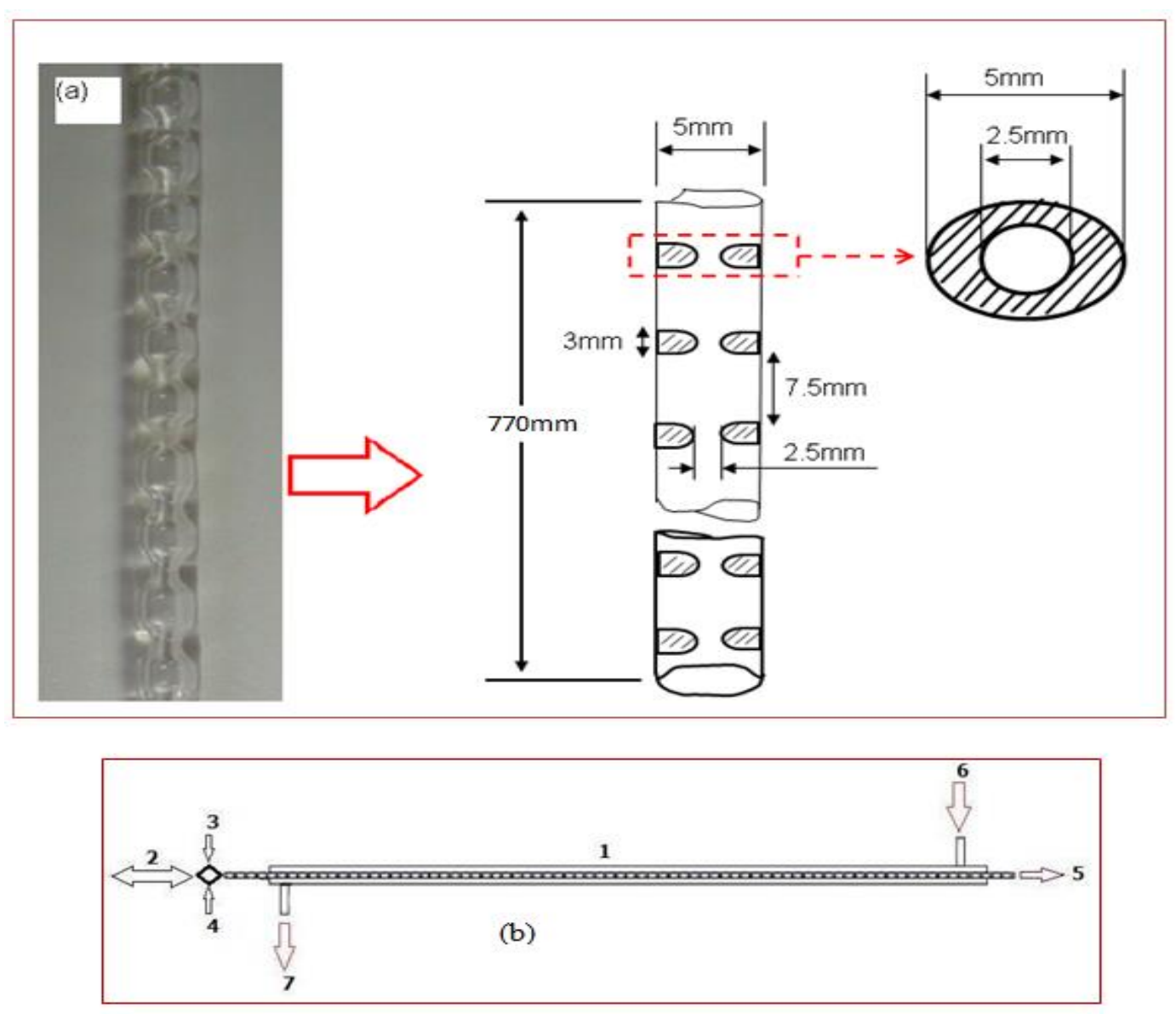

Figure 4: Configuration of the reactors [42]. (a) Integrally baffled meso-OBR and the schematics of the internal configuration, (b) diagrammatic view of the meso-OBR used in the reaction: jacketed meso-OBR (1), oscillation line (2), Feed lines (3 \& 4), product/sampling point (5), hot water in (6), and hot water out (7).

One of the meso-OBRs was fully packed with the $\sim 500 \mu$ m beads of the Amberlyst ${ }^{\mathrm{TM}} 70-\mathrm{SO}_{3} \mathrm{H}$ resin, and the second meso-OBR with the $\sim 600 \mu \mathrm{m}$ beads of the Amberlyst ${ }^{\mathrm{TM}}$ A26-OH resin. The catalysts had been conditioned by washing 5 times with $20 \mathrm{~mL}$ of anhydrous methanol before packing. The base and top of the packed meso-OBRs were sealed with $5 \mathrm{~mm}$ discs of stainless steel wire mesh (\#60) of $160 \mu \mathrm{m}$ wire diameter and $263 \mu \mathrm{m}$ apertures to constrain the catalyst beads from leaving the reactor. Each reactor was then assembled with the base, connected through Swagelok fittings to three Confluent syringe pumps (Eurodyne Ltd). One of these pumps was used to provide the oscillations at $4.5 \mathrm{~Hz}$ frequency and $4 \mathrm{~mm}$ amplitude, and the other two to provide the net flows of triacetin and methanol as shown in Figure 5. 


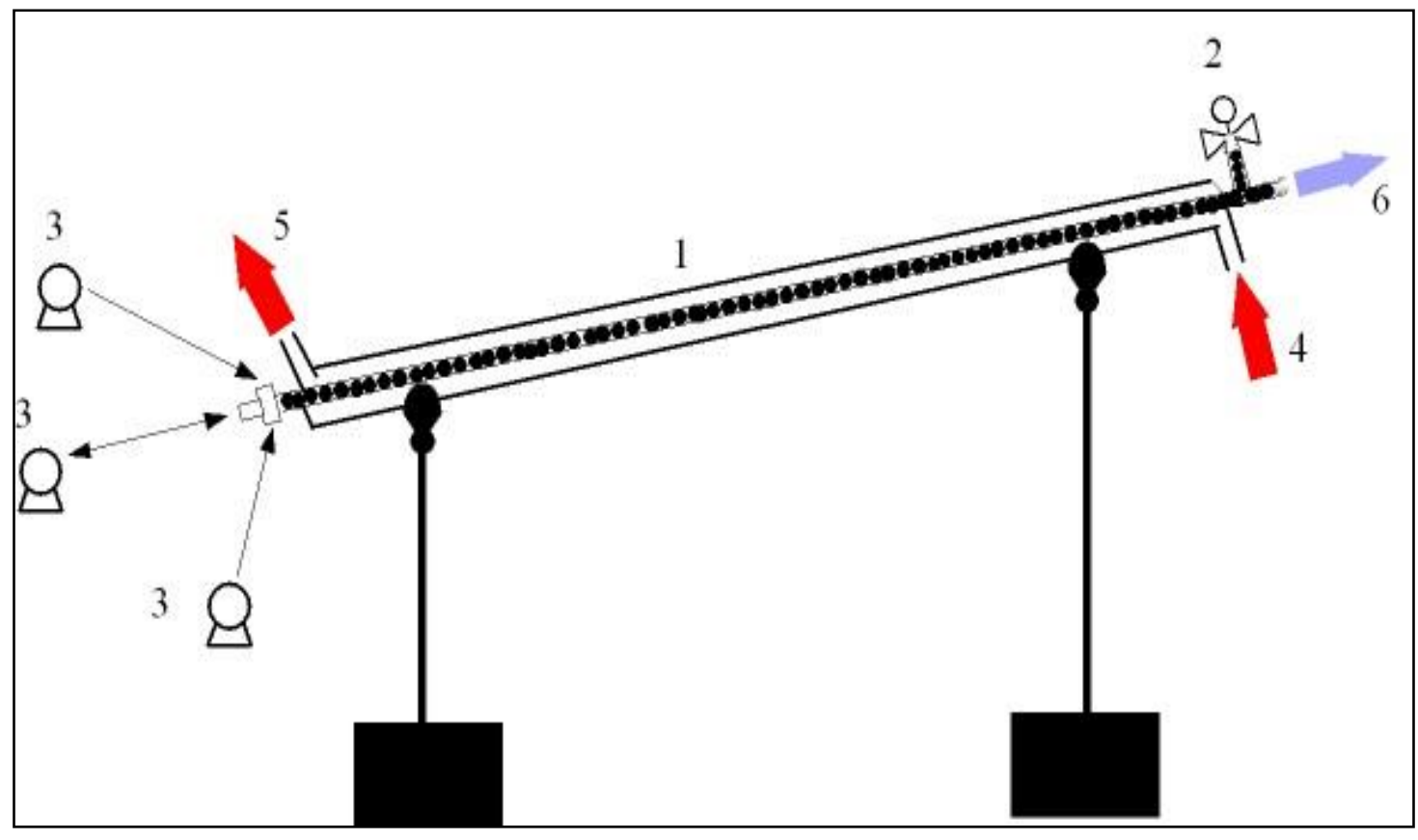

Figure 5: Set-up for the screening: (1) packed bed of Amberlyst ${ }^{\mathrm{TM}}$ resin, (2) sampling point, (3) syringe pumps, heating water - (4) inlet, (5) outlet (6) exit product.

The syringe pump used for oscillation was connected to the base of the reactor, and the fluid mixing inside the reactor provided by adjusting the speed of the piston movement (frequency) and the oscillation amplitude (center-to-peak) of the pump [39]. The syringe pumps were controlled via a PC interface. The pumps were initialised and set at the required mixing intensity (amplitude and frequency) and reactants net flow rates prior to each experiment.

The volumes of the reactors after packing (with $9 \mathrm{~g}$ of Amberlyst ${ }^{\mathrm{TM}} 70-\mathrm{SO}_{3} \mathrm{H}$, or $8 \mathrm{~g}$ of Amberlyst $^{\mathrm{TM}}$ A26-OH) were $8.3 \mathrm{~mL}$ and $9.2 \mathrm{~mL}$, respectively, and the volume of the reactor without packing was 15.2mL. The reaction temperature was maintained by the circulation of heated water through the jackets of the meso-OBRs using a temperature-controlled water bath (Ecoline, LUADA E100). All the reactions were performed at $50^{\circ} \mathrm{C}$ to reduce formation of vapour/gas phase inside the reactor due to the low boiling points of acetone $\left(56^{\circ} \mathrm{C}\right)$ and methyl acetate $\left(57^{\circ} \mathrm{C}\right)$. 
Triacetin and methanol (and acetone) feeds were dispensed from reservoirs maintained at the reaction temperature of $50^{\circ} \mathrm{C}$ inside the water bath. Steady state performances of the packed meso-OBRs were evaluated for the triacetin transesterification using methanol to triacetin molar ratio of $6: 1$ and residence times of $0.5 \mathrm{~min}-30 \mathrm{~min}$ for the Amberlyst ${ }^{\mathrm{TM}} \mathrm{A} 26-\mathrm{OH}$, and methanol to triacetin molar ratio of 30:1 and residence times of $2.5 \mathrm{~min}-60 \mathrm{~min}$ for the Amberlyst ${ }^{\mathrm{TM}} 70-\mathrm{SO}_{3} \mathrm{H}$. Prior to each experiment, continuous circulation of methanol over the Amberlyst ${ }^{\mathrm{TM}}$ resin packed bed was carried out to swell catalysts and make the pores network accessible to the reactants [43, 44]. All the experiments were carried out at oscillation conditions of $\geq 4 \mathrm{~mm}$ amplitude and $\geq 4.5 \mathrm{~Hz}\left(\operatorname{Re}_{\mathrm{o}} \geq 160\right)$ where the reaction was clearly mixing independent (Figure 6). Incidentally, the Figure 6 below illustrates well the fact that the interaction of baffles and fluid oscillation leads to an earlier onset of mixing independence.

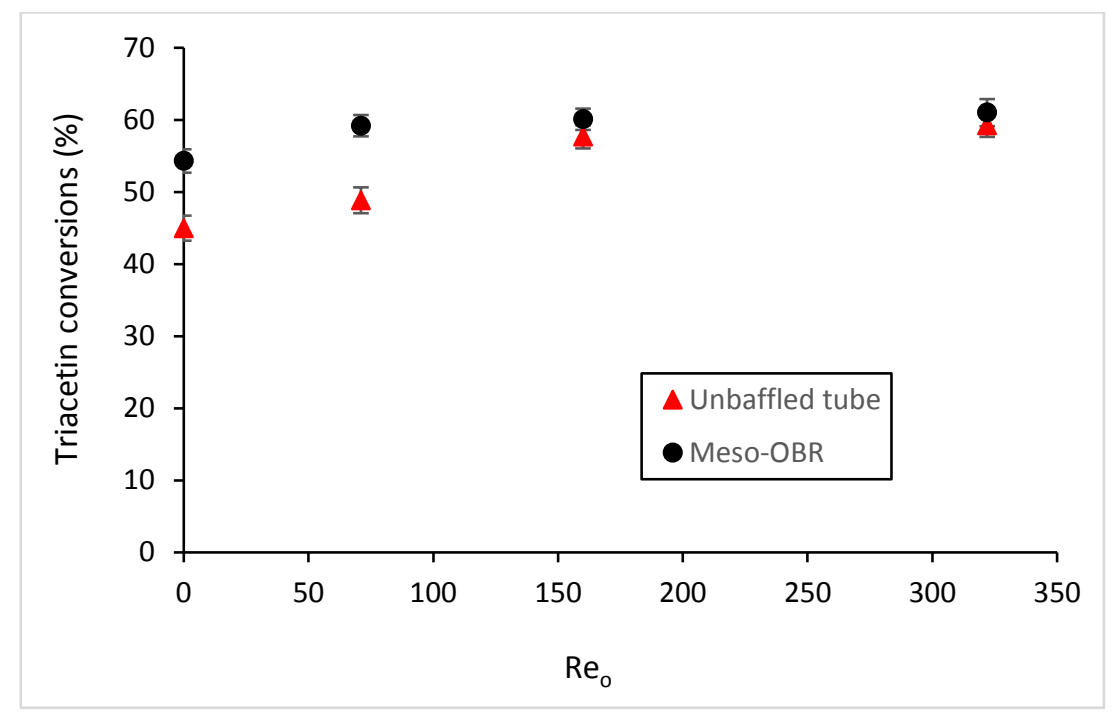

Figure 6: Mixing independent regions for transesterification at $50^{\circ} \mathrm{C}, 6: 1$ methanol to triacetin molar ratio and $1 \mathrm{~min}$ residence time using $8 \mathrm{~g}$ Amberlyst ${ }^{\mathrm{TM}} \mathrm{A} 26-\mathrm{OH}$ resin catalyst packed in meso-OBR and un-baffled tubular reactor $\left(\operatorname{Re}_{\mathrm{n}}=24\right)$.

\subsection{Simultaneous triacetin transesterification and conversion of glycerol to solketal (one-stage)}

Triacetin transesterification over the meso-OBR packed with 9g Amberlyst ${ }^{\mathrm{TM}} 70-\mathrm{SO}_{3} \mathrm{H}$ (as shown in Figure 5) and simultaneous conversion of glycerol by-product to solketal through reactive coupling with acetone was investigated. The experimental conditions were methanol-acetone-triacetin molar 
ratio of $6: 4: 1,50^{\circ} \mathrm{C}$ temperature and residence times of $2.5 \mathrm{~min}-30 \mathrm{~min}$. An acetone to glycerol molar ratio of 4:1 was used, based on 1:1 stoichiometry of triacetin and glycerol in a complete transesterification. A set of experiments was conducted to investigate the direct reactions of glycerol with acetone using the meso-OBR packed with Amberlyst ${ }^{\mathrm{TM}} 70-\mathrm{SO}_{3} \mathrm{H}$. The glycerol used was diluted in methanol at 1:1 volume ratio to reduce its viscosity and ease the flow through the PVM syringe pumped line, and to examine any interference of methanol in the proposed integrated biodiesel process. The experiments were performed at a 4:1 acetone to glycerol molar ratio as reported elsewhere [45] using residence times of $2.5 \mathrm{~min}-30 \mathrm{mins}$ and $50^{\circ} \mathrm{C}$ reaction temperature.

\subsection{Two-stage triacetin transesterification and in-situ conversion of glycerol to solketal}

A two-stage process for triacetin transesterification and in situ conversion of the glycerol by-product to solketal was investigated using two interconnected meso-OBRs packed with Amberlyst ${ }^{\mathrm{TM}}$ A26-OH catalyst ( $1^{\text {st }}$ reactor) and Amberlyst ${ }^{\mathrm{TM}} 70-\mathrm{SO}_{3} \mathrm{H}$ catalyst $\left(2^{\text {nd }}\right.$ reactor), as shown in the Figure 7. Continuous transesterification at a methanol to triacetin molar ratio of 6:1 was carried out in the presence of the Amberlyst ${ }^{\mathrm{TM}} \mathrm{A} 26-\mathrm{OH}$ catalyst in the $1^{\text {st }}$ reactor to form methyl ester and glycerol, followed by an online reactive coupling of the glycerol with acetone over the Amberlyst ${ }^{\mathrm{TM}} 70-\mathrm{SO}_{3} \mathrm{H}$ catalyst ( $2^{\text {nd }}$ reactor) to form solketal. The net flows of the feed correspond to $6: 4: 1$ methanol-acetonetriacetin molar ratio. This process was screened at $50^{\circ} \mathrm{C}$ and residence times of $5-35 \mathrm{~min}$. About $0.5 \mathrm{~mL}$ of sample was collected through the sampling units at the outputs of the $1^{\text {st }}$ and $2^{\text {nd }}$ reactors for each residence time 


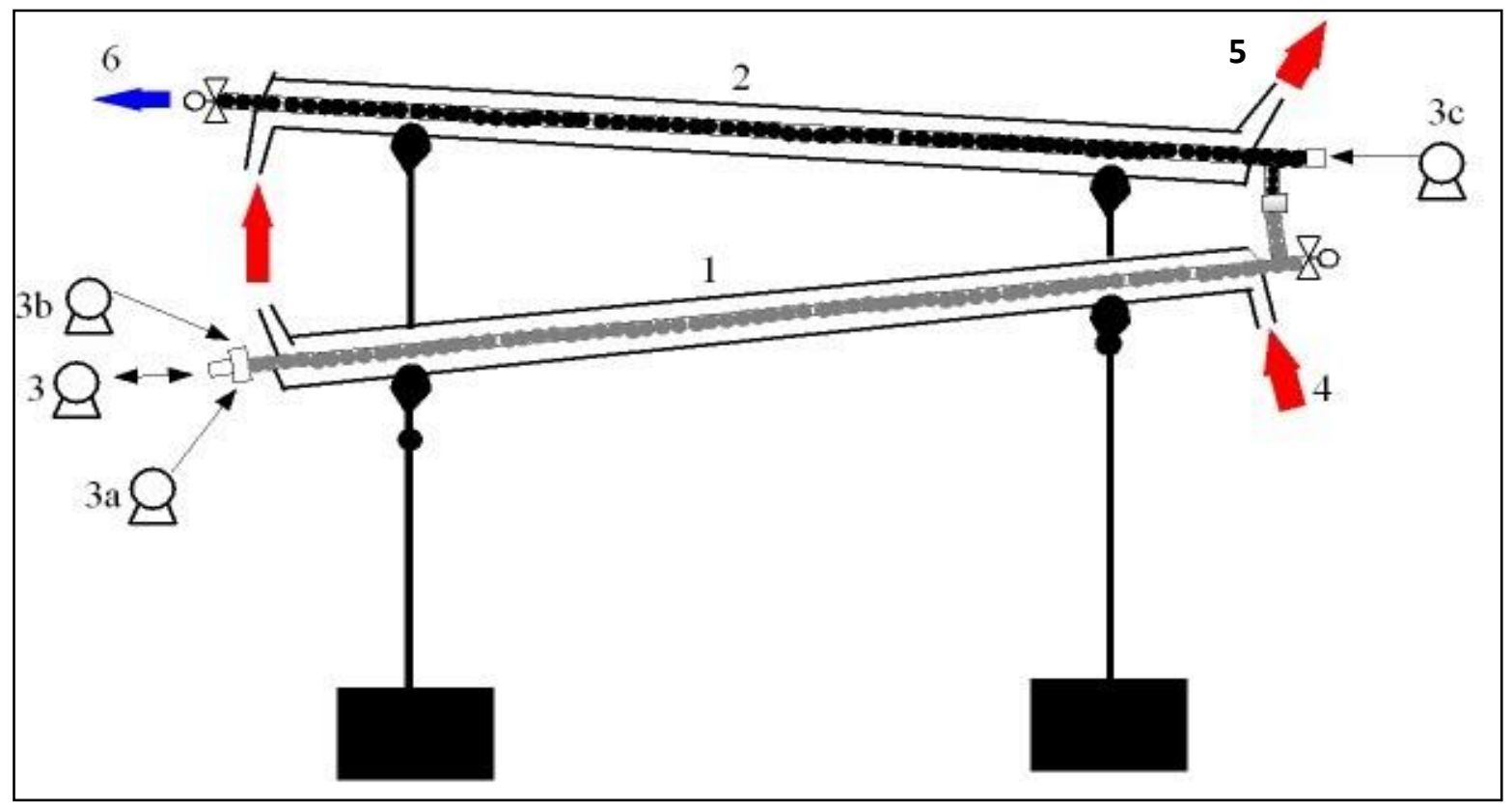

Figure 7: Experimental set-up for catalytic dual bed: (1) Amberlyst ${ }^{\mathrm{TM}}$ A26-OH bed; (2) Amberlyst ${ }^{\mathrm{TM}}$ 70-SO $\mathrm{S}_{3} \mathrm{H}$ bed; (3) syringe pumps: oscillation (3), methanol (3a), triacetin (3b), acetone (3c), hot water - inlet (4); outlet (5), (6) sampling unit.

\subsection{Sample Collections and Analysis}

Approximately $0.5 \mathrm{~mL}$ of sample was collected each time. All the samples were taken in $2 \mathrm{~mL}$ vials and stored at $-20{ }^{\circ} \mathrm{C}$ for GC analysis. The gas chromatography method used in the analysis of the triacetin reaction was adopted from an existing study [46], with some modifications in the GC conditions. The modified GC method was applied for determinations of triacetin, methyl acetate, glycerol and solketal in samples, using 2-propanol as a solvent for all the preparations. Calibration curves for the analysis were prepared with known concentrations of triacetin, methanol, methyl acetate, glycerol and solketal, using toluene as the GC internal standard. Stock solutions for these analytes were prepared to the concentrations of 500mg per millilitre of 2-propanol for each component. The toluene internal standard was mixed with 2-propanol to the concentration of 1:16 (v/v) toluene to 2propanol volume ratio, corresponding to about $48 \mathrm{mg} / \mathrm{mL}$. Various volumes of the stock solutions were measured into $5 \mathrm{~mL}$ vials using micropipettes, followed by the additions of a $0.5 \mathrm{~mL}$ of the $1: 16(\mathrm{v} / \mathrm{v})$ toluene internal standard solution, to achieve analyte/toluene weight fractions in the range of 0 - 
$8 \mathrm{wt} / \mathrm{wt}$. $1 \mathrm{~mL}$ of 2-propanol was added to each vial to keep the GC signals within the detection limit. About $0.5 \mu \mathrm{L}$ of each mixture was manually injected into the GC using $5 \mu \mathrm{L}$ SGE GC syringe.

Separations of various components in the calibration mixture and the triacetin reaction samples were achieved using Varian CP Wax capillary (BPX70) column and ramped oven temperature programme. The oven initial temperature of $50^{\circ} \mathrm{C}$ was held for 10 minutes, ramped at $30^{\circ} \mathrm{C} / \mathrm{min}$ to $180^{\circ} \mathrm{C}$ and held for 10 minutes, and then ramped at $30^{\circ} \mathrm{C} / \mathrm{min}$ to $210^{\circ} \mathrm{C}$ and held for $14.67 \mathrm{~min}$. Calibration curves for various components $\left(\mathrm{R}^{2}>0.99\right)$ were generated by the correlations of the peak areas of the FID signals (mV.s) with the known concentrations of the chemical species in the mixtures.

The reaction samples were analysed using the calibration data and the above oven temperature programme. Approximately 50.0 - 100.0mg of sample was carefully weighed in a $2 \mathrm{~mL}$ vial using A\&D HR-200 weighing balance $( \pm 1 \mathrm{mg})$. This was followed by addition of $0.5 \mathrm{~mL}$ of the $1: 16(\mathrm{v} / \mathrm{v})$ toluene internal standard solution, dilution of the sample mixture with $1 \mathrm{~mL}$ of 2-propanol and shaking to obtain a homogeneous solution. About $0.5 \mu \mathrm{L}$ of the prepared sample was manually injected into the GC using the $5 \mu \mathrm{L}$ SGE GC syringe. Amounts of triacetin, methyl acetate, glycerol and solketal in the samples were quantified based on the calibration curves using Equation (3). Conversions of the triacetin, methyl acetate, glycerol and solketal were calculated based on the Equations (4) - (7).

$$
\mathrm{W}_{\mathrm{a}}=\mathrm{R}_{a} \cdot\left(\frac{\mathrm{A}_{\mathrm{a}}}{\mathrm{A}_{\mathrm{is}}}\right) \cdot\left(\frac{V_{i s} \cdot \mathrm{C}_{\mathrm{is}}}{\mathrm{M}_{s}}\right)
$$

Triacetin conversion $(\%)=100 *\left(\frac{[\text { Triacetin }]_{0}-[\text { Triacetin }]_{t}}{[\text { Triacetin }]_{0}}\right)$

Methyl acetate conversion $(\%)=100 *\left(\frac{[\text { Methyl acetate }]_{t}}{3 *[\text { Triacetin }]_{0}}\right)$

Glycerol conversion $(\%)=100 *\left(\frac{[\text { Glycerol }]_{t}}{[\text { Triacetin }]_{0}}\right)$

Solketal conversion $(\%)=100 *\left(\frac{[\text { Solketal }]_{t}}{[\text { Glycerol }]_{0}}\right)=100 *\left(\frac{[\text { Solketal }]_{t}}{[\text { Triacetin }]_{0}}\right)$ 
Where:

$\mathrm{R}_{\mathrm{a}}$ : Response factor (the inverse of the slope of the calibration curve) for the analyte, $\mathrm{W}_{\mathrm{a}}$ : weight fraction of the analyte in the sample; $\mathrm{M}_{\mathrm{s}}$ : mass of the sample (mg); $\mathrm{A}_{\mathrm{a}}$ : Peak area of the analyte (mV.s); $\mathrm{C}_{\mathrm{is}}$ : concentration of the internal standard solution $(\mathrm{mg} / \mathrm{mL}) ; \mathrm{A}_{\mathrm{is}}$ : Peak area of the internal standard $(\mathrm{mV} . \mathrm{s}) ; \mathrm{V}_{\mathrm{is}}$ : volume of the internal standard used $(\mathrm{mL})$.

\subsection{Results and Discussions}

\subsection{Steady States Performance of the Packed Meso-OBRs}

Figure 8 shows the steady state triacetin conversions for transesterifications in meso-OBR at $50^{\circ} \mathrm{C}$ using 6:1 methanol to triacetin molar ratio with Amberlyst ${ }^{\mathrm{TM}}$ A26-OH catalyst at ramped residence times of $0.5 \mathrm{~min}-30 \mathrm{~min}$ (Figure $8(\mathrm{a})$ ), and 30:1 methanol to triacetin molar ratio with Amberlsyt ${ }^{\mathrm{TM}}$ $70-\mathrm{SO}_{3} \mathrm{H}$ catalyst at ramped residence times of $2.5 \mathrm{~min}-60 \mathrm{~min}$ (Figure $8(\mathrm{~b})$ ). The results clearly showed that a step-change occurred between residence times, and that steady states were achieved for all the ramped residence times investigated. This agrees with an existing study on triglyceride transesterification in meso-OBR using homogeneous base-catalysed [37, 39], and this demonstrates that the flows inside the Amberlyst ${ }^{\mathrm{TM}}$ catalyst packed meso-OBR system were in the plug flow regime at the experimental conditions, resulting in a tight control of residence time and effective mixing.

Steady states were achieved quickly in the packed meso-OBRs with little variation in triacetin conversions at induction times in the range of $1.2-1.4$ times residence time. The time spent by a continuous flow reactor in start-up stage is an important factor, as short start-up time reduces the amount of feedstock required, and the wastes generated at the induction stage. The induction times

obtained for the Amberlyst ${ }^{\mathrm{TM}}$ packed meso-OBR were consistent with 1.5 times residence reported for a meso-OBR in homogeneous base-catalysed transesterification of rapeseed oil [39]. 

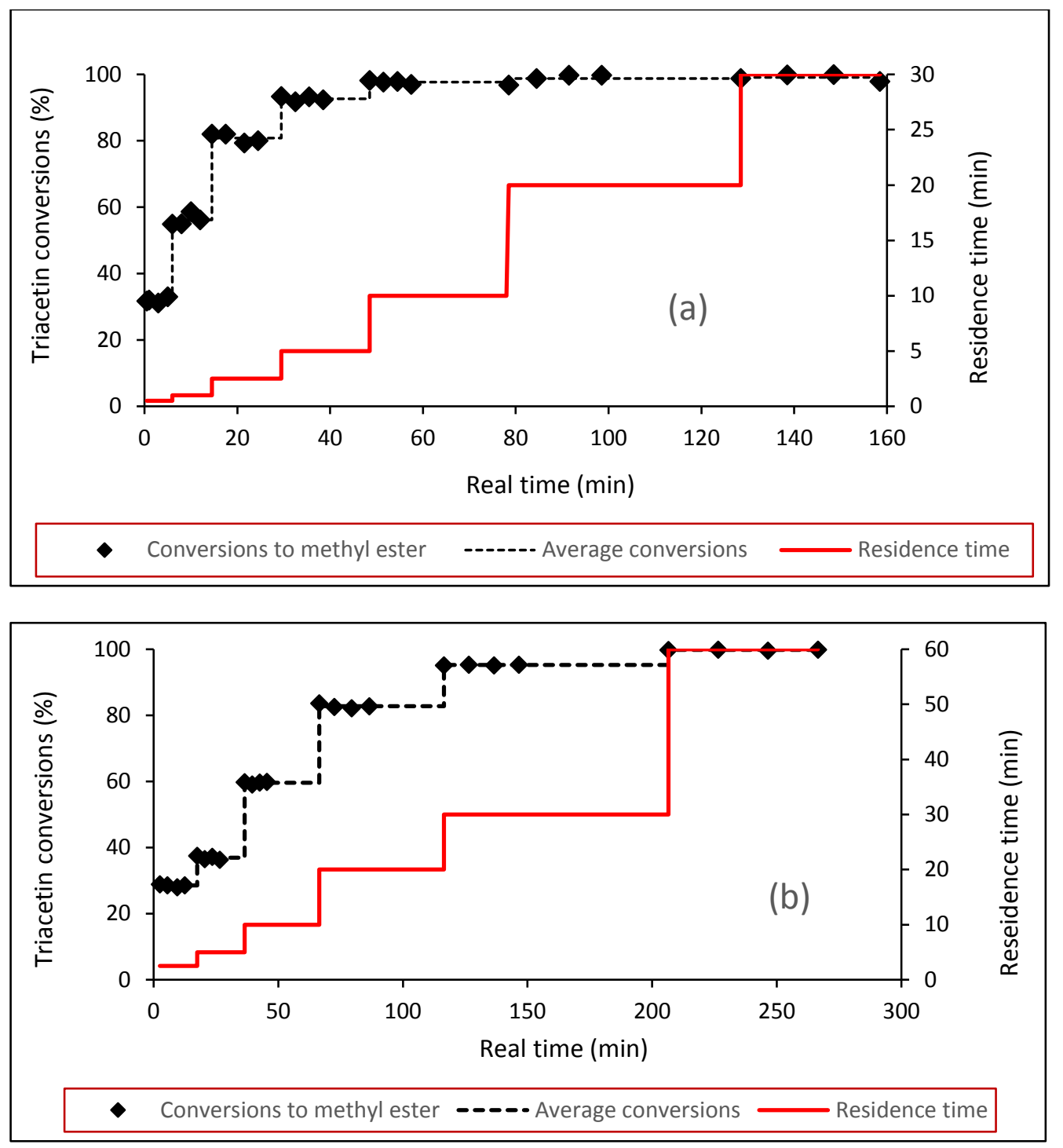

Figure 8: Multi-steady states triacetin conversions for transesterification in meso-OBR at $50^{\circ} \mathrm{C}$ using: (a) 6:1 methanol to triacetin molar ratio, Amberlsyt ${ }^{\mathrm{TM}} \mathrm{A} 26-\mathrm{OH}$ resin and ramped residence times of $0.5 \mathrm{~min}-30 \mathrm{~min}$; (b) 30:1 methanol to triacetin molar ratio, Amberlsyt ${ }^{\mathrm{TM}} 70-\mathrm{SO}_{3} \mathrm{H}$ resin and ramped residence times of $2.5 \mathrm{~min}-60 \mathrm{~min}$.

Generally, the Amberlyst ${ }^{\mathrm{TM}}$ A26-OH packed meso-OBR achieved higher rates of triacetin conversion as shown in Figure 8(a), than the Amberlyst ${ }^{\mathrm{TM}} 70-\mathrm{SO}_{3} \mathrm{H}$ in Figure 8(b). The triacetin conversions for the Amberlyst ${ }^{\mathrm{TM}} \mathrm{A} 26-\mathrm{OH}$ increased from $32.0 \pm 0.9 \%$ at $0.5 \mathrm{~min}$ residence time, $80.8 \pm 1.4 \%$ at $2.5 \mathrm{~min}$, $92.7 \pm 0.8 \%$ at $5 \mathrm{~min}, 97.9 \pm 0.5 \%$ at $10 \mathrm{~min}$, to $98.8 \pm 1.4 \%$ at $20 \mathrm{~min}$, for the continuous multi-steady states ramp at $6: 1$ methanol to triacetin molar ratio and $50^{\circ} \mathrm{C}$ reaction temperature. For the Amberlyst ${ }^{\mathrm{TM}}$ $70-\mathrm{SO}_{3} \mathrm{H}$ system, the triacetin conversions were $28.5 \pm 0.4 \%$ at $2.5 \mathrm{~min}$ residence time, $36.9 \pm 0.5 \%$ at 
5min, $59.6 \pm 0.4 \%$ at $10 \mathrm{~min}, 82.8 \pm 0.6 \%$ at $20 \mathrm{~min}, 95.2 \pm 0.1 \%$ at $30 \mathrm{~min}$ and $99.8 \pm 0.1 \%$ at $60 \mathrm{~min}$, for the continuous multi-steady states ramp at 30:1 methanol to triacetin molar ratio and $50^{\circ} \mathrm{C}$ reaction temperature. The small variance in the triacetin conversions at the steady states is an indication of plug flow behaviour and good mixing in the meso-OBR. There was no reduction in the triacetin conversions in any of the Amberlyst ${ }^{\mathrm{TM}}$ packed meso-OBRs on prolonged use, showing that these Amberlyst ${ }^{\mathrm{TM}}$ resin catalysts have high degree of catalytic stability and reusability, in agreement with existing studies $[7-9,12]$.

Catalytic activities of the Amberlyst ${ }^{\mathrm{TM}}$ resins used in this study were compared with other ionexchange resin catalysts in terms of their turnover frequency (TOF). TOF is defined as turnover number (TON) per unit time, while TON is the mole of a reactant converted to product per mole of active sites of the catalyst. Due to the cumulative nature of TON, a better comparison of catalytic activities for heterogeneous catalysts can only be obtained by evaluations of their TOF, usually calculated at the initial reaction rates. TOF of Amberlyst $^{\mathrm{TM}}$ A26-OH catalyst for the triacetin transesterification was $61.2 \times 10^{-3} \mathrm{~s}^{-1}$, more than a factor of 12 higher than $5.0 \times 10^{-3} \mathrm{~s}^{-1}$ for the Amberlyst ${ }^{\mathrm{TM}} 70-\mathrm{SO}_{3} \mathrm{H}$ catalyst. As expected, the triacetin reaction proceeds slower with the Amberlyst ${ }^{\mathrm{TM}} 70-\mathrm{SO}_{3} \mathrm{H}$ catalyst (Figure 9), a trend that has been observed for homogeneous acid and base catalysts. According to previous studies [47, 48], homogeneous base-catalysed triglyceride transesterification proceed at higher reaction rates than acid catalysts, about 4000 times faster [47]. 
Table 1: Turn over frequency of some catalysts

\begin{tabular}{lll}
\hline Catalysts & TOF $\left(10^{-3} \mathrm{~s}^{-1}\right)$ & Reference \\
\hline Amberlyst $^{\mathrm{TM}}$ A26-OH & $61.2^{\mathrm{a}}$ & This study \\
Amberlyst $^{\mathrm{TM}} 70-\mathrm{SO}_{3} \mathrm{H}$ & $5.0^{\mathrm{a}}$ & This study \\
Amberlyst-15 & $1.9^{\mathrm{b}}-6.4^{\mathrm{c}}$ & {$[46]$} \\
Nafion NR50 & $2.4^{\mathrm{b}}-58.6^{\mathrm{c}}$ & {$[46]$} \\
\hline
\end{tabular}

a: calculated using the active sites from elemental analysis (nitrogen and sulphur), $2.59 \mathrm{mmol} / \mathrm{g}$ for Amberlyst $^{\mathrm{TM}} 70-\mathrm{SO}_{3} \mathrm{H}$ and $4.21 \mathrm{mmol} / \mathrm{g}$ for Amberlyst ${ }^{\mathrm{TM}}$ A26-OH.

b: obtained using active sites in swollen states.

c: obtained using active sites from $\mathrm{NH}_{3}$ chemisorption

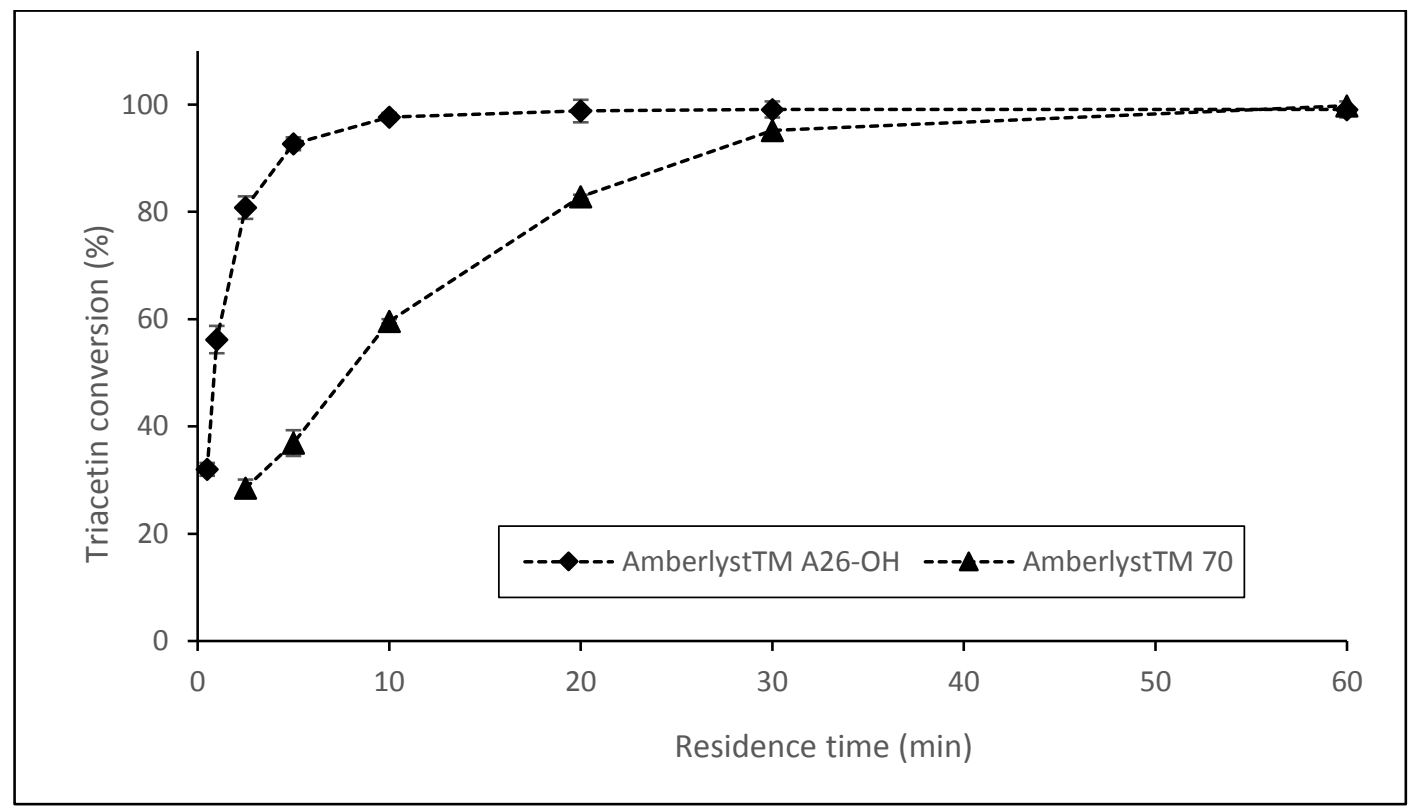

Figure 9: Average steady states triacetin conversions for transesterification at $50^{\circ} \mathrm{C}$ and various residence times, for a meso-OBRs packed with Amberlyst ${ }^{\mathrm{TM}} \mathrm{A} 26-\mathrm{OH}$ at 6:1 methanol to triacetin molar ratio, and a meso-OBR with Amberlyst ${ }^{\mathrm{TM}} 70-\mathrm{SO}_{3} \mathrm{H}$ at 30:1 methanol to triacetin molar ratio.

As shown Table 1, the TOF for the Amberlyst ${ }^{\mathrm{TM}} 70-\mathrm{SO}_{3} \mathrm{H}$ catalyst in this work compares well with that of other $-\mathrm{SO}_{3} \mathrm{H}$ functionalised polymers. For instance, TOF in the range of $1.9-6.4 \times 10^{-3} \mathrm{~s}^{-1}$ for Amberlys-15 and $2.4-58.6 \times 10^{-3} \mathrm{~s}^{-1}$ for Nafion NR50 have been reported [46]. The active sites of the Amberlyst ${ }^{\mathrm{TM}}$ A26-OH and Amberlyst ${ }^{\mathrm{TM}} 70-\mathrm{SO}_{3} \mathrm{H}$ used in this study were obtained from nitrogen and sulphur contents analysis, respectively. The high TOF of the Nafion NR50 compared to other $-\mathrm{SO}_{3} \mathrm{H}$ 
ion-exchange could be attributed to strong sulphonic acid sites present in the perfluorinated Nafion NR50 resin polymer support. Currently, no TOF has been reported for Amberlyst ${ }^{\mathrm{TM}}$ A26-OH in triglyceride (triacetin) transesterification, hence the findings here cannot be compared with any existing study.

\subsection{Effects of Water on Amberlyst ${ }^{\mathrm{TM}}$ A26-OH and Amberlyst ${ }^{\mathrm{TM}}$ 70-SO $3 \mathrm{H}$ Packed Meso-OBRs}

Although water is not a by-product of transesterification, a robust catalytic system that could tolerate small amounts of water in the feedstock is desirable. Most importantly, water is a by-product of the reaction of glycerol and acetone. Therefore, it is necessary to ensure that the reactively-formed water does not adsorb permanently on the active sites of the heterogeneous catalyst. Figure 10 shows the results of the investigation on the effects of water on the Amberlyst ${ }^{\mathrm{TM}}$ catalysts for triacetin transesterification with anhydrous methanol, water-laden methanol and controlled water spiking. Figure 10(a) shows that the Amberlyst ${ }^{\mathrm{TM}}$ A26-OH system was not water-tolerant, as any addition of water permanently deactivated its basic active sites. For instance, the steady state triacetin conversion decreased from $98.3 \pm 1.1 \%$ with anhydrous methanol, to $92.7 \pm 1.0 \%$ after spiking with $0.5 \mathrm{~mL}$ of distilled water, in a continuous triacetin transesterification using a meso-OBR packed with Amberlyst ${ }^{\mathrm{TM}} \mathrm{A} 26-\mathrm{OH}$ at $50^{\circ} \mathrm{C}, 10 \mathrm{~min}$ residence and $6: 1$ methanol to triacetin molar ratio. When the anhydrous methanol flow was switched to water-laden methanol (2.5vol\% water), the triacetin conversion drastically reduced to $22.8 \pm 1.3 \%$, from the "new" steady state conversion of $92.7 \pm 1.0 \%$ achieved after spiking with $0.5 \mathrm{~mL}$. The Amberlyst ${ }^{\mathrm{TM}} \mathrm{A} 26-\mathrm{OH}$ never recovered its full catalytic activity even after the methanol flow was switched back to anhydrous methanol, as only $27.4 \pm 1.0 \%$ triacetin conversion was achieved. 

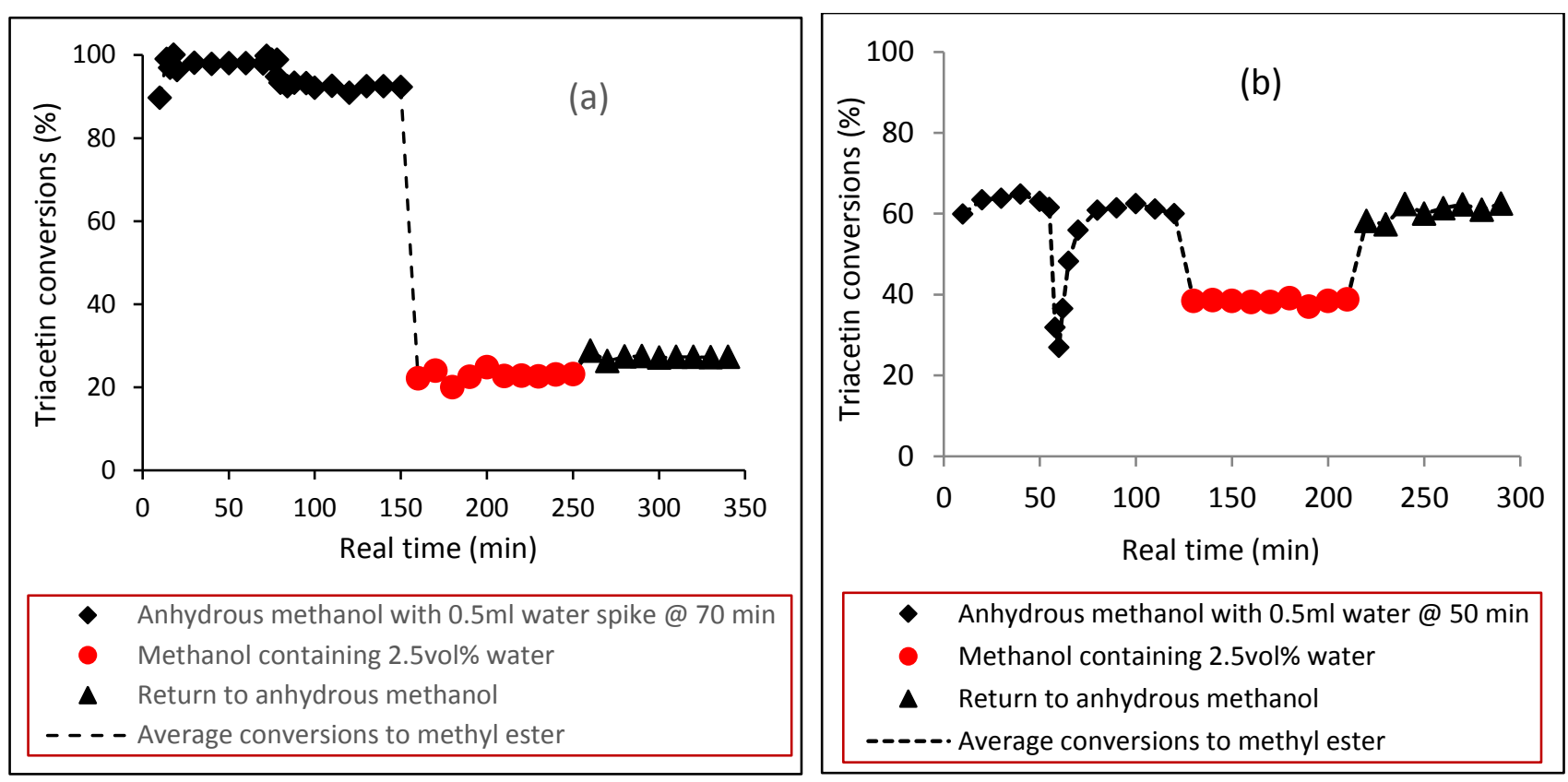

Figure 10: Robustness of the meso-OBR platform for rapid screening of effects of water on continuous triacetin transesterification in meso-OBR at $50^{\circ} \mathrm{C}$ and $10 \mathrm{~min}$ residence using, (a) Amberlyst ${ }^{\mathrm{TM}}$ A26 and 6:1 methanol/triacetin molar ratio, (b) Amberlyst ${ }^{\mathrm{TM}} 70$ and 30:1 methanol/triacetin molar ratio.

In sharp contrast to the Amberlyst ${ }^{\mathrm{TM}} \mathrm{A} 26-\mathrm{OH}$ system, investigations of effects of water on the Amberlyst ${ }^{\mathrm{TM}} 70-\mathrm{SO}_{3} \mathrm{H}$ showed that this catalyst was tolerant to water (Figure 10(b)). Steady state triacetin conversion of $62.8 \pm 1.8 \%$ was obtained before spiking with $0.5 \mathrm{~mL}$ of water, and $61.5 \pm 0.7 \%$ after the water spiking, for transesterification over the Amberlyst ${ }^{\mathrm{TM}} 70-\mathrm{SO}_{3} \mathrm{H}$ packed meso-OBR at $50^{\circ} \mathrm{C}, 10 \mathrm{~min}$ residence and $30: 1$ methanol to triacetin molar ratio. The largest effects of the water spiking were observed at about $60 \mathrm{~min}$ running time, corresponding to $10 \mathrm{~min}$ (one residence time) after the water spiking with triacetin conversion of $26.9 \%$. The Amberlyst ${ }^{\mathrm{TM}} 70-\mathrm{SO}_{3} \mathrm{H}$ system recovered its catalytic activity at 2 residence times after water spiking, which was slightly longer than the induction times of $1.2-1.4$ residence times for the Amberlyst ${ }^{\mathrm{TM}} 70-\mathrm{SO}_{3} \mathrm{H}$ packed reactor. This suggests a competitive but reversible adsorption of water on the $-\mathrm{SO}_{3} \mathrm{H}$ active sites of the catalyst.

The triacetin conversions for the Amberlyst ${ }^{\mathrm{TM}} 70-\mathrm{SO}_{3} \mathrm{H}$ system dropped from the average values of $62.8 \pm 1.8 \%$ to $38.4 \pm 0.6 \%$ when the anhydrous methanol flow was switched to methanol containing 
$2.5 \mathrm{vol} \%$ water. However, the Amberlyst ${ }^{\mathrm{TM}} 70-\mathrm{SO}_{3} \mathrm{H}$ catalyst entirely recovered its catalytic activity after the water-laden methanol flow was switched back to anhydrous methanol, achieving steady state triacetin conversion of $61.6 \pm 1.0 \%$. This demonstrates that water does not permanently deactivate the Amberlyst ${ }^{\mathrm{TM}} 70-\mathrm{SO}_{3} \mathrm{H}$ catalyst in triglyceride transesterification, consistent with previous study by the authors on the effects of water on the catalyst during carboxylic acid esterification [42]. This catalyst could be used in reactions where wet feedstock or reactively-formed water could be encountered, such as in esterification process and acetalisation reaction of glycerol and acetone. Ideally, such reactions require water-tolerant acid catalysts to prevent catalyst deactivation. One of the advantages of continuous screening in transesterification reactions where water could be encountered is that in-flow of fresh methanol into the meso-OBR helps to prevent any accumulation of water on the catalyst surface $[6,42]$. This is unlike batch experiments, where any water added into the system remained in the reaction mixture and in contact with the catalyst.

The observed permanent deactivation of the Amberlyst ${ }^{\mathrm{TM}}$ A26-OH catalyst by water was unexpected, as it was believed that continuous in-flow of fresh methanol into the packed bed of Amberlyst ${ }^{\mathrm{TM}}$ A26$\mathrm{OH}$ would remove water adsorbed on the catalyst surface. Mechanism for the Amberlyst ${ }^{\mathrm{TM}}$ A26-OH deactivation by water has not been reported. Elemental analysis for carbon, nitrogen and sulphur (CNS) was performed on the fresh and spent Amberlyst ${ }^{\mathrm{TM}}$ resins to investigate any change in their compositions during reactions. Nitrogen content of the Amberlyst ${ }^{\mathrm{TM}}$ A26-OH resin decreased from $5.9 \mathrm{wt} \%(\sim 4.21 \mathrm{mmol} / \mathrm{g})$ in fresh catalyst to $5.5 \mathrm{wt} \%(\sim 3.93 \mathrm{mmol} / \mathrm{g})$ after deactivation by methanol containing $2.5 \mathrm{vol} \%$ water, while the carbon contents increased from $64.2 \mathrm{wt} \%$ to $66.1 \mathrm{wt} \%$. On the contrary, the Amberlyst ${ }^{\mathrm{TM}} 70-\mathrm{SO}_{3} \mathrm{H}$ showed no change in composition for the fresh and spent catalysts, as the carbon and sulphur contents remained consistent at $43.2 \mathrm{wt} \%$ and $8.3 \mathrm{wt} \%(\sim 2.59 \mathrm{mmol} / \mathrm{g})$, respectively. There was no substantial change in the nitrogen content of the Amberlyst ${ }^{\mathrm{TM}} \mathrm{A} 26-\mathrm{OH}$ to account for the degree of deactivation observed, therefore, the deactivation process was not due to loss 
of active sites by leaching. The increase in the carbon content of the deactivated Amberlyst ${ }^{\mathrm{TM}}$ A26$\mathrm{OH}$ resin suggest that the catalyst was being poisoned through irreversible reactions with an organic intermediate formed during water spiking. A possible mechanism for the permanent deactivation could be poisoning by acetic acid formed via aqueous hydrolysis of triacetin and methyl acetate. This leads to replacement of the $\mathrm{OH}^{-}$ions on the Amberlyst ${ }^{\mathrm{TM}} \mathrm{A} 26-\mathrm{OH}$ resin with acetate ions $\left(\mathrm{CH}_{3} \mathrm{COO}^{-}\right)$, leading to an increased carbon content of the deactivated catalyst.

\subsection{Reactive Coupling of Glycerol and Acetone to Produce Solketal during Transesterification}

Figure 11 shows the glycerol-acetone reaction at 4:1 acetone to glycerol molar ratio (Figure 11(a)), and the one-stage process for continuous triacetin transesterification at methanol-acetone-triacetin molar ratio of 6:4:1 (Figure $11(\mathrm{~b})$ ), using a meso-OBR packed with Amberlyst ${ }^{\mathrm{TM}} 70-\mathrm{SO}_{3} \mathrm{H}$ catalyst at $50^{\circ} \mathrm{C}$ temperature and residence times of $2.5 \mathrm{~min}-30 \mathrm{~min}$. The direct glycerol condensation was used to evaluate the activity of the Amberlyst ${ }^{\mathrm{TM}} 70-\mathrm{SO}_{3} \mathrm{H}$ for acetalisation reaction. As shown in the Figure 11 (a), the glycerol conversion to solketal increased rapidly from $46.9 \pm 2.7 \%$ at $5 \mathrm{~min}$ to $74.0 \pm 1.8 \%$ at $20 \mathrm{~min}$ residence time, and afterwards improved gradually. For instance, the solketal formation was $80.6 \pm 2.1 \%$ at $30 \mathrm{~min}$ residence time. The solketal conversion in this study compares well, with $86 \%$ yield reported for glycerol-acetone reaction at 6:1 molar ratio using Amberlyst-35 after 15min reaction time [49], and solketal conversions of $75.5 \%-80.7 \%$ that were achieved after $30 \mathrm{~min}$ reaction time using Ar-SBA-15 catalyst [50]. Findings in this study showed that reactive coupling of glycerol and acetone can be carried out in the presence of methanol, consistent with reports elsewhere [51, 52]. Therefore, an integrated biodiesel process - producing fatty acid methyl esters and solketal through reactive coupling of glycerol with acetone is feasible in biodiesel plants. Removal of the reactivelyformed water from the system may be required to overcome equilibrium limitations and shift the reaction towards more solketal formation. 

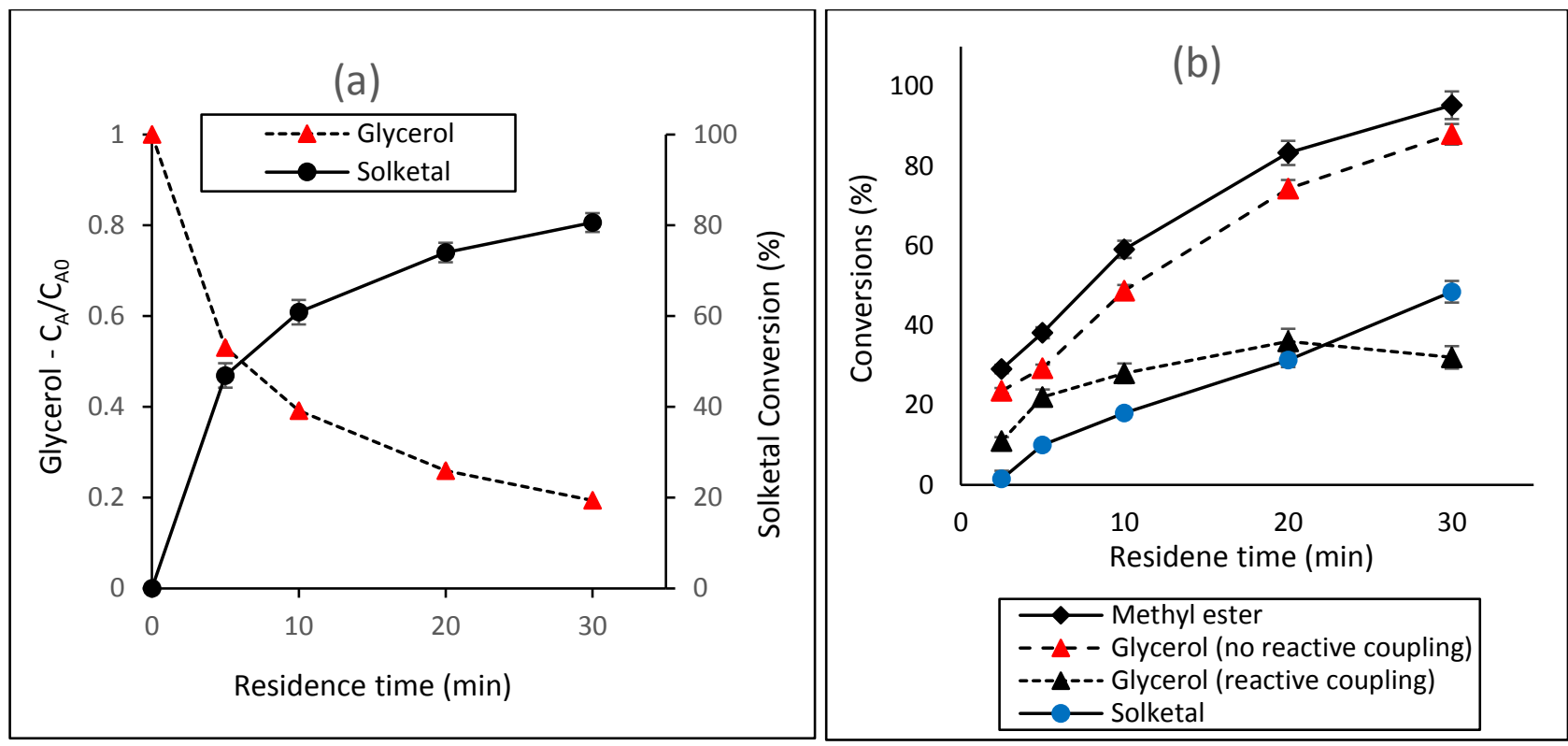

Figure 11: Plots of conversions versus residence time for reactions using Amberlyst ${ }^{\mathrm{TM}} 70-\mathrm{SO}_{3} \mathrm{H}$ packed meso-OBR at $50^{\circ} \mathrm{C}$ : (a) direct acetalisation of glycerol at 4:1 acetone to glycerol molar ratio to produce solketal; (b) triacetin transesterification and reactive glycerol-acetone coupling at methanol-triacetin-acetone molar ratio of 30:1:4, to form methyl ester and solketal.

The one-stage process for triacetin transesterification at methanol-triacetin-acetone molar ratio of 6:1:4 over the Amberlyst ${ }^{\mathrm{TM}} 70-\mathrm{SO}_{3} \mathrm{H}$ packed meso-OBR at $50^{\circ} \mathrm{C}$ achieved $95.3 \pm 2.0 \%$ triacetin to methyl esters and $48.5 \pm 2.7 \%$ solketal conversions after 30 min reaction time (Figure 11(b)). The conversions of triacetin to glycerol at $30 \mathrm{~min}$ residence time was $88.0 \pm 2.8 \%$ without acetone, and this was reduced to $32.1 \pm 2.6 \%$ through reactive coupling with acetone. Lower solketal conversion in the one-stage process compared to the direct glycerol-acetone reaction could be attributed to the use of large excess of methanol (methanol-triacetin-acetone of 30:1:4) which reduces the concentrations of the acetone and glycerol, and consequently their lower reaction rates in the system. The one-stage process has an advantage that both the acetalisation and transesterification reactions are carried out simultaneously in one reactor. However, this process requires large excess of methanol and would take longer time due to the slower rate of acid-catalysed transesterification. 
Figure 12 shows the results of the two-stage process for continuous reactions of triacetin, methanol and acetone. The triacetin was reacted with methanol at 6:1 molar ratio over Amberlyst ${ }^{\mathrm{TM}} \mathrm{A} 26-\mathrm{OH}$ catalyst in the $1^{\text {st }}$ reactor, followed by online reactive coupling of the glycerol by-product with acetone over Amberlyst ${ }^{\mathrm{TM}} 70-\mathrm{SO}_{3} \mathrm{H}$ catalyst in the $2^{\text {nd }}$ reactor. There was a rapid triacetin transesterification in the $1^{\text {st }}$ reactor (Figure 12(a)), achieving $97.7 \pm 2.3 \%$ triacetin to methyl acetate and $91.7 \pm 1.5 \%$ glycerol conversions at $10 \mathrm{~min}$ residence time. Further increase in the reaction time to $25 \mathrm{~min}$ resulted in near complete conversion of the triacetin to methyl ester $(99.1 \pm 2.0 \%)$ and glycerol $(98.0 \pm 1.3 \%)$.

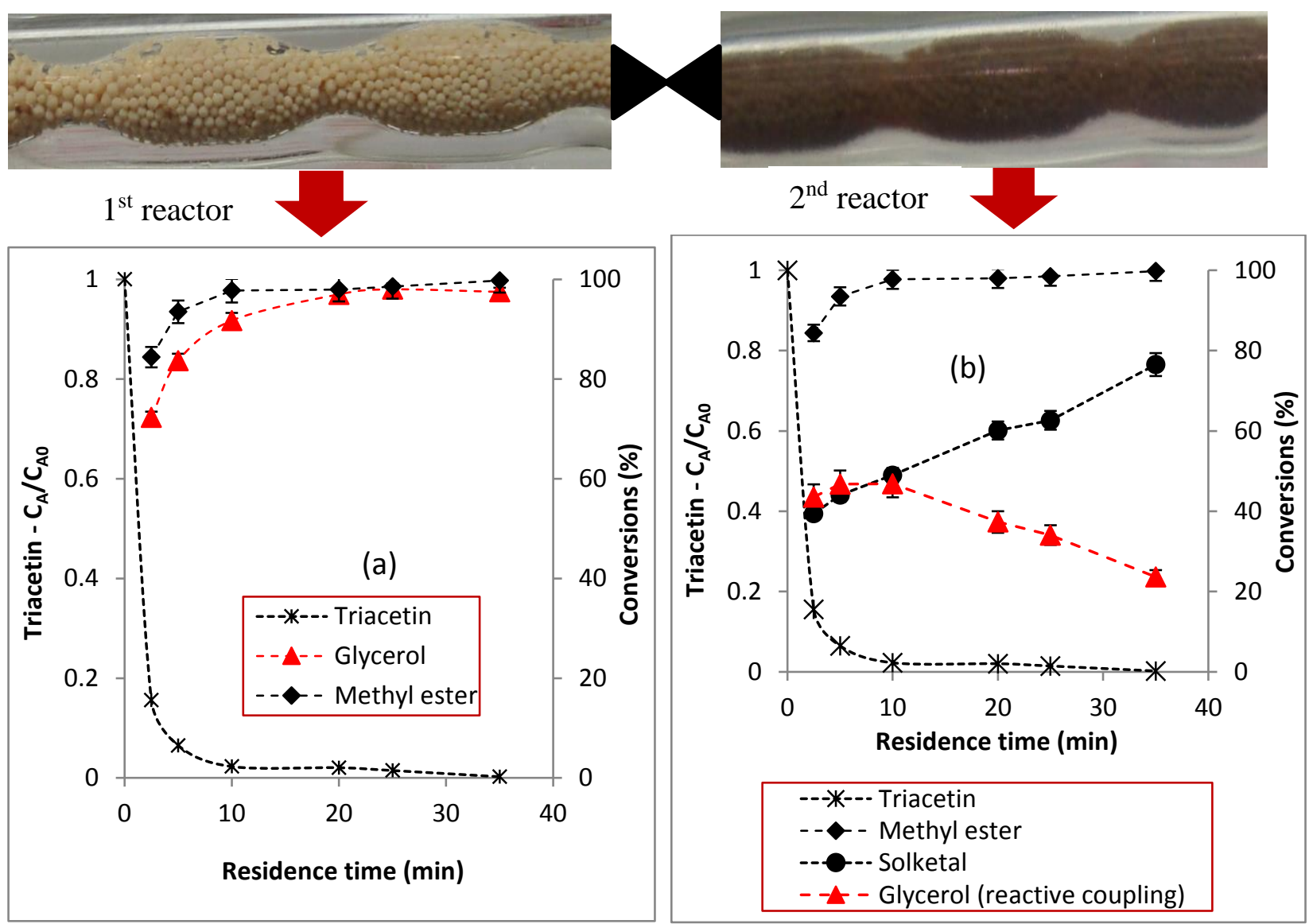

Figure 12: Two-stage transesterification process: (a) $1^{\text {st }}$ stage transesterification at 6:1 methanol to triacetin molar ratio and $60^{\circ} \mathrm{C}$ using Amberlsyt ${ }^{\mathrm{TM}} \mathrm{A} 26-\mathrm{OH}$ packed meso-OBR; (b) $2^{\text {nd }}$ stage online reactive coupling of glycerol from the $1^{\text {st }}$ reactor with acetone at a methanol-triacetin-acetone molar ratio of $6: 1: 4$ and $50^{\circ} \mathrm{C}$ using a meso-OBR packed with Amberlsyt ${ }^{\mathrm{TM}} 70-\mathrm{SO}_{3} \mathrm{H}$.

The output streams of the $2^{\text {nd }}$ reactor showed rapid in-situ conversions of the glycerol to solketal (Figure 12 (b)), with solketal formation increasing linearly from $39.4 \pm 1.4 \%$ at $2.5 \mathrm{~min}$ to $76.5 \pm 2.8 \%$ 
at $35 \mathrm{~min}$ residence time. Glycerol co-production was reduced from $98.0 \pm 1.3 \%$ conversion in the $1^{\text {st }}$ reactor to $23.6 \pm 2.1 \%$ in the $2^{\text {nd }}$ reactor (about $76 \%$ reduction in glycerol by-product) after $35 \mathrm{~min}$ through reactive coupling with acetone. There was no indication at this reaction time that the solketal formation was approaching equilibrium. This strongly suggests that methanol could mitigate the effects of reactively-formed water on the thermodynamic equilibrium of the solketal formation reactions. A study has shown that use of methanol could have the potential in reducing the cost of solketal production from glycerol-acetone reaction [52]. The higher rates of solketal formation in the two-stage process $(76.5 \%)$, as compared to the one-stage in $(48.5 \%)$, are probably due to the application of lower methanol molar ratio for the triacetin transesterification in the $1^{\text {st }}$ reactor. Also, the use of Amberlsyt ${ }^{\mathrm{TM}} \mathrm{A} 26-\mathrm{OH}$ catalyst in the $1^{\text {st }}$ reactor achieved higher rates of glycerol formation compared to the Amberlsyt ${ }^{\mathrm{TM}} 70-\mathrm{SO}_{3} \mathrm{H}$. These resulted in higher concentration gradients for the glycerol and acetone in the $2^{\text {nd }}$ reactor, hence the increased rates of solketal production. As shown in Figure 12 (b), no substantial conversions of triacetin to methyl ester occurred in the $2^{\text {nd }}$ reactor, consequently, the triacetin and methyl ester conversions from the output streams of the $1^{\text {st }}$ and $2^{\text {nd }}$ reactors were similar. This was attributed to the lower rate of the acid-catalysed transesterification. The two-stage process is more resource-efficient, as it requires less methanol than the one-stage. Another advantage of the two-stage process is the possible reduction in reaction time due to the higher rates of base-catalysed triglyceride transesterification. The solketal conversion achieved in the twostage process $(76.5 \pm 2.8 \%)$ compares well with $80.6 \pm 2.1 \%$ for the direct glycerol-acetone reaction using the Amberlyst ${ }^{\mathrm{TM}} 70-\mathrm{SO}_{3} \mathrm{H}$ packed meso-OBR.

The processes investigated in this study could fundamentally change the conventional biodiesel production strategy. They have the potential to reduce the cost of biodiesel processing through contemporaneous productions of solketal from glycerol. The methyl esters produced when operating at high conversions would contain approximately $10 \mathrm{wt} \%$ solketal, which could be left as biodiesel fuel 
additive. Use of solketal as an additive reduces biodiesel's viscosity [25], and leads to reduced gum formation and 2.5 points enhancement in octane number when blended at $1-5$ vol\% in gasoline [26]. Considering the use of heterogeneous catalysts in both stages, this process would therefore require very little downstream purification.

\subsection{Conclusion}

A biodiesel process for contiunous transesterifcation of triglycerides to form methyl esters, whilst simultaneously converting the glycerol by-product into a useful product (solketal) using acetone is described. The study considered two-stage and one-stage catalytic process routes. In the two-stage process, two interconnected meso-OBRs packed with amberlyst resin catalysts were used: a basic Amberlyst ${ }^{\mathrm{TM}} \mathrm{A} 26-\mathrm{OH}$ in the $1^{\text {st }}$ reactor to catalyse transesterfication of triacetin with methanol, and an acidic Amberlyst ${ }^{\mathrm{TM}} 70-\mathrm{SO}_{3} \mathrm{H}$ in the $2^{\text {nd }}$ reactor to catalyse the online coupling of glycerol and acetone to form solketal. Triacetin was converted to $99.1 \pm 2.0 \%$ methyl acetate and $98.0 \pm 1.3 \%$ glycerol after $25 \mathrm{~min}$ residence time in the $1^{\text {st }}$ reactor. This was followed by online reactive coupling of the glycerol with acetone in the $2^{\text {nd }}$ reactor to achieve solketal conversions of $76.5 \pm 2.8 \%$ at $35 \mathrm{~min}$ residence times, reducing the glycerol content of the output stream by about $76 \%$. In the one-stage process, triacetin transesterification and glycerol condensation with acetone were achieved in a mesoOBR packed with the Amberlyst ${ }^{\mathrm{TM}} 70-\mathrm{SO}_{3} \mathrm{H}$. The single-stage reaction of triacetin and methanol in the presence of acetone achieved lower solketal conversion, e.g. $48.5 \pm 2.7 \%$ at $30 \mathrm{~min}$ residence time. This study demonstrates that triglyceride transesterification could be modified to produce methyl esters and solketal, minimising the co-production of glycerol. The processes investigated here could be optimised to provide future biodiesel production strategy.

The Amberlyst ${ }^{\mathrm{TM}}$ resins are stable and can be reused as heterogeneous catalysts for triglyceride transesterification. However, the Amberlyst ${ }^{\mathrm{TM}}$ A26-OH system was not water-tolerant, as water 
caused permanent deactivation of its basic active sites. The steady state triacetin conversion decreased from $98.3 \pm 1.1 \%$ with anhydrous methanol, to $27.4 \pm 0.6 \%$ after reactions with methanol containing $2.5 \mathrm{vol} \%$ water, for continuous triacetin transesterification using a meso-OBR packed with Amberlyst ${ }^{\mathrm{TM}} \mathrm{A} 26-\mathrm{OH}$ at $50^{\circ} \mathrm{C}, 10 \mathrm{~min}$ residence and $6: 1$ methanol to triacetin molar ratio. The Amberlyst ${ }^{\mathrm{TM}} 70-\mathrm{SO}_{3} \mathrm{H}$ catalyst was found to be tolerant to water. The steady state triacetin conversions for this catalyst remained consistent before $(62.8 \pm 1.8 \%)$ and after $(61.6 \pm 1.0 \%)$ water spiking, for transesterification over the Amberlyst ${ }^{\mathrm{TM}} 70-\mathrm{SO}_{3} \mathrm{H}$ packed meso-OBR at $50^{\circ} \mathrm{C}, 10 \mathrm{~min}$ residence and 30:1 methanol to triacetin molar ratio.

The meso-OBR platform allowed a wide range of experimental conditions to be investigated continuously in a single experiment, through multi-steady state screening. This rendered process development faster than would be the case when using batch reactions where separate experiments must be conducted to compare initial rates under different conditions. Most other continuous screening platforms would not be able to accommodate the relatively large Amberlyst ${ }^{\mathrm{TM}}$ resin beads. Use of the meso-OBRs in process development saved time and substantially reduced the amount of feedstock required and the waste generated.

\section{Acknowledgements}

The authors would like thank Dow Chemical Company, Netherland, for supplying the Amberlyst ${ }^{\mathrm{TM}}$ A26-OH and Amberlyst ${ }^{\mathrm{TM}} 70$ resins used in this study. This work was supported by the UK Engineering and Physical Sciences Research Council (EPSRC) through grant number EP/K026216/1 (Cleaning Land for Wealth). 


\section{References}

[1] G. Vicente, M. Martínez, J. Aracil, Integrated biodiesel production: a comparison of different homogeneous catalysts systems, Bioresour. Technol. 92 (2004) 297-305.

[2] M.E. Bambase, N. Nakamura, J. Tanaka, M. Matsumura, Kinetics of hydroxide-catalyzed methanolysis of crude sunflower oil for the production of fuel-grade methyl esters, J. Chem. Technol. Biotechnol. 82 (2007) 273-280.

[3] G.W. Huber, S. Iborra, A. Corma, Synthesis of transportation fuels from biomass: Chemistry, catalysts, and engineering, Chem. Rev. 106 (2006) 4044-4098.

[4] B. Freedman, E.H. Pryde, T.L. Mounts, Variables affecting the yields of fatty esters from transesterified vegetable oils, J. Am. Oil Chem. Soc. 61 (1984) 1638-1643.

[5] P.T. Anastas, M.M. Kirchhoff, T.C. Williamson, Catalysis as a foundational pillar of green chemistry, Appl. Catal. A: Gen. 221 (2001) 3-13.

[6] V.C. Eze, A.N. Phan, C. Pirez, A.P. Harvey, A.F. Lee, K. Wilson, Heterogeneous catalysis in an oscillatory baffled flow reactor, Catal. Sci. Technol. 3 (2013) 2373-2379.

[7] N. Shibasaki-Kitakawa, H. Honda, H. Kuribayashi, T. Toda, T. Fukumura, T. Yonemoto, Biodiesel production using anionic ion-exchange resin as heterogeneous catalyst, Bioresour. Technol. 98 (2007) 416-421.

[8] C.E.T. Co, M.C. Tan, J.A.R. Diamante, L.R.C. Yan, R.R. Tan, L.F. Razon, Internal mass-transfer limitations on the transesterification of coconut oil using an anionic ion exchange resin in a packed bed reactor, Catal. Today 174 (2011) 54-58.

[9] M.G. Falco, C.D. Córdoba, M.R. Capeletti, U. Sedran, Basic ion exchange resins as heterogeneous catalysts for biodiesel synthesis, Adv. Mater. Res. 132 (2010) 220-227.

[10] Y. Feng, A. Zhang, J. Li, B. He, A continuous process for biodiesel production in a fixed bed reactor packed with cation-exchange resin as heterogeneous catalyst, Bioresour. Technol. 102 (2011) 3607-3609.

[11] B.M.E. Russbueldt, W.F. Hoelderich, New sulfonic acid ion-exchange resins for the preesterification of different oils and fats with high content of free fatty acids, Appl. Catal. A: Gen. 362 (2009) 47-57.

[12] S.M. de Rezende, M. de Castro Reis, M.G. Reid, P. Lúcio Silva Jr, F.M.B. Coutinho, R.A. da Silva San Gil, E.R. Lachter, Transesterification of vegetable oils promoted by poly(styrenedivinylbenzene) and poly(divinylbenzene), Appl. Catal. A: Gen. 349 (2008) 198-203.

[13] C.S. MacLeod, A.P. Harvey, A.F. Lee, K. Wilson, Evaluation of the activity and stability of alkalidoped metal oxide catalysts for application to an intensified method of biodiesel production, Chem. Eng. J. 135 (2008) 63-70. 
[14] R. Rodrigues, N. Isoda, M. Gonçalves, F.C.A. Figueiredo, D. Mandelli, W.A. Carvalho, Effect of niobia and alumina as support for Pt catalysts in the hydrogenolysis of glycerol, Chem. Eng. J. 198199 (2012) 457-467.

[15] R. Ciriminna, C.D. Pina, M. Rossi, M. Pagliaro, Understanding the glycerol market, Eur. J. Lipid Sci. Technol. 116 (2014) 1432-1439.

[16] J. George, Y. Patel, S.M. Pillai, P. Munshi, Methanol assisted selective formation of 1,2-glycerol carbonate from glycerol and carbon dioxide using $\mathrm{nBu} 2 \mathrm{SnO}$ as a catalyst, J. Mol. Catal. Chem. 304 (2009) 1-7.

[17] J.R. Ochoa-Gómez, O. Gómez-Jiménez-Aberasturi, B. Maestro-Madurga, A. PesqueraRodríguez, C. Ramírez-López, L. Lorenzo-Ibarreta, et al., Synthesis of glycerol carbonate from glycerol and dimethyl carbonate by transesterification: Catalyst screening and reaction optimization, Appl. Catal. A: Gen. 366 (2009) 315-324.

[18] M. Malyaadri, K. Jagadeeswaraiah, P.S. Sai Prasad, N. Lingaiah, Synthesis of glycerol carbonate by transesterification of glycerol with dimethyl carbonate over $\mathrm{Mg} / \mathrm{Al} / \mathrm{Zr}$ catalysts, Appl. Catal. A: Gen. 401 (2011) 153-157.

[19] L. Li, T.I. Koranyi, B.F. Sels, P.P. Pescarmona, Highly-efficient conversion of glycerol to solketal over heterogeneous Lewis acid catalysts, Green Chem. 14 (2012) 1611-1619.

[20] N. Suriyaprapadilok, B. Kitiyanan, Synthesis of Solketal from Glycerol and Its Reaction with Benzyl Alcohol, Energy Procedia 9 (2011) 63-69.

[21] J.R. Dodson, T.d.C.M. Leite, N. S. Pontes, B. Peres Pinto, C.J.A. Mota, Green acetylation of solketal and glycerol formal by heterogeneous acid catalysts to form a biodiesel fuel additive, ChemSusChem. 7 (2014) 2728-2734.

[22] R. Rodrigues, M. Goncalves, D. Mandelli, P.P. Pescarmona, W.A. Carvalho, Solvent-free conversion of glycerol to solketal catalysed by activated carbons functionalised with acid groups, Catal. Sci. Technol. 4 (2014) 2293-2301.

[23] W.K. Teng, G.C. Ngoh, R. Yusoff, M.K. Aroua, A review on the performance of glycerol carbonate production via catalytic transesterification: Effects of influencing parameters, Energy Convers. Manage. 88 (2014) 484-497.

[24] A. Behr, J. Eilting, K. Irawadi, J. Leschinski, F. Lindner, Improved utilisation of renewable resources: New important derivatives of glycerol, Green Chem. 10 (2008) 13-30.

[25] J.A. Melero, G. Vicente, G. Morales, M. Paniagua, J. Bustamante, Oxygenated compounds derived from glycerol for biodiesel formulation: Influence on EN 14214 quality parameters, Fuel 89 (2010) 2011-2018.

[26] C.J.A. Mota, C.X.A. da Silva, N. Rosenbach, J. Costa, F. da Silva, Glycerin derivatives as fuel additives: the addition of glycerol/acetone ketal (solketal) in gasolines, Energy Fuels 24 (2010) 27332736.

[27] C. Ramshaw, Process Intensification and green chemistry, Green Chem. 1 (1999) G15-G17.

[28] Y.C. Lin, K.H. Hsu, J.F. Lin, Rapid palm-biodiesel production assisted by a microwave system and sodium methoxide catalyst, Fuel 115 (2014) 306-311. 
[29] C.C. Liao, T.W. Chung, Optimization of process conditions using response surface methodology for the microwave-assisted transesterification of Jatropha oil with $\mathrm{KOH}$ impregnated $\mathrm{CaO}$ as catalyst, Chem. Eng. Res. Des. 91 (2013) 2457-2464.

[30] D. Kumar, G. Kumar, Poonam, C.P. Singh, Fast, easy ethanolysis of coconut oil for biodiesel production assisted by ultrasonication, Ultrason. Sonochem. 17 (2010) 555-559.

[31] L.T. Thanh, K. Okitsu, Y. Sadanaga, N. Takenaka, Y. Maeda, H. Bandow, Ultrasound-assisted production of biodiesel fuel from vegetable oils in a small scale circulation process, Bioresour. Technol. 101 (2010) 639-645.

[32] J.A. Colucci, E. Borrero, F. Alape, Biodiesel from an alkaline transesterification reaction of soybean oil using ultrasonic mixing, J. Am. Oil Chem. Soc. 82 (2005) 525-530.

[33] Z. Qiu, J. Petera, L.R. Weatherley, Biodiesel synthesis in an intensified spinning disk reactor, Chem. Eng. J. 210 (2012) 597-609.

[34] E.E. Kalu, K.S. Chen, T. Gedris, Continuous-flow biodiesel production using slit-channel reactors, Bioresour. Technol. 102 (2011) 4456-4461.

[35] Z. Wen, X. Yu, S.-T. Tu, J. Yan, E. Dahlquist, Intensification of biodiesel synthesis using zigzag micro-channel reactors, Bioresour. Technol. 100 (2009) 3054-3060.

[36] J. Sun, J. Ju, L. Ji, L. Zhang, N. Xu, Synthesis of biodiesel in capillary microreactors, Ind. Eng. Chem. Res. 47 (2008) 1398-1403.

[37] A.N. Phan, A.P. Harvey, M. Rawcliffe, Continuous screening of base-catalysed biodiesel production using New designs of mesoscale oscillatory baffled reactors, Fuel Process. Technol. 92 (2011) 1560-1567.

[38] A.P. Harvey, M.R. Mackley, T. Seliger, Process intensification of biodiesel production using a continuous oscillatory flow reactor, J. Chem. Technol. Biotechnol. 78 (2003) 338-341.

[39] A.N. Phan, A.P. Harvey, V. Eze, Rapid production of biodiesel in mesoscale oscillatory baffled reactors, Chem. Eng. Technol. 35 (2012) 1214-1220.

[40] A. Orjuela, A.J. Yanez, A. Santhanakrishnan, C.T. Lira, D.J. Miller, Kinetics of mixed succinic acid/acetic acid esterification with Amberlyst 70 ion exchange resin as catalyst, Chem. Eng. J. 188 (2012) 98-107.

[41] P.F. Siril, H.E. Cross, D.R. Brown, New polystyrene sulfonic acid resin catalysts with enhanced acidic and catalytic properties, J. Mol. Catal. A: Chem. 279 (2008) 63-68.

[42] V.C. Eze, J.C. Fisher, A.N. Phan, A.P. Harvey, Intensification of carboxylic acid esterification using a solid catalyst in a mesoscale oscillatory baffled reactor platform, Chem. Eng. J. 322 (2017) $205-214$.

[43] R. Tesser, M. Di Serio, L. Casale, G. Carotenuto, E. Santacesaria, Absorption of water/methanol binary system on ion-exchange resins, Can. J. Chem. Eng. 88 (2010) 1044-1053.

[44] E. Van de Steene, J. De Clercq, J.W. Thybaut, Ion-exchange resin catalyzed transesterification of ethyl acetate with methanol: gel versus macroporous resins, Chem. Eng. J. 242 (2014) 170-179. 
[45] C.N. Fan, C.H. Xu, C.Q. Liu, Z.Y. Huang, J.Y. Liu, Z.X. Ye, Catalytic acetalization of biomass glycerol with acetone over TiO2-SiO2 mixed oxides, React. Kinet. Mech. Catal. 107 (2012) 189-202.

[46] D.E. López, J.G. Goodwin Jr, D.A. Bruce, E. Lotero, Transesterification of triacetin with methanol on solid acid and base catalysts, Appl. Catal. A: Gen. 295 (2005) 97-105.

[47] J.M. Cervero, J. Coca, S. Luque, Production of biodiesel from vegetable oils, Grasas Aceites 59 (2008) 76-83.

[48] B. Freedman, R.O. Butterfield, E.H. Pryde, Transesterification kinetics of soybean oil 1, J. Am. Oil Chem. Soc. 63 (1986) 1375-1380.

[49] M.R. Nanda, Z. Yuan, W. Qin, H.S. Ghaziaskar, M.-A. Poirier, C. Xu, A new continuous-flow process for catalytic conversion of glycerol to oxygenated fuel additive: catalyst screening, Appl. Energy 123 (2014) 75-81.

[50] G. Vicente, J.A. Melero, G. Morales, M. Paniagua, E. Martin, Acetalisation of bio-glycerol with acetone to produce solketal over sulfonic mesostructured silicas, Green Chem. 12 (2010) 899-907.

[51] C.X.A. da Silva, C.J.A. Mota, The influence of impurities on the acid-catalyzed reaction of glycerol with acetone, Biomass Bioenergy 35 (2011) 3547-3551.

[52] M.R. Nanda, Z. Yuan, W. Qin, H.S. Ghaziaskar, M.A. Poirier, C. Xu, Catalytic conversion of glycerol to oxygenated fuel additive in a continuous flow reactor: process optimization, Fuel 128 (2014) 113-119. 